\title{
ANÁLISE DE PROVENIÊNCIA, IDADES U-Pb DA FONTE, MATURIDADE TEXTURAL E PALEOCORRENTES DO GRUPO MARICÁ (EDIACARANO DO RIO GRANDE DO SUL)
}

\author{
ANA PAULA DE MEIRELES REIS PELOSI ${ }^{1} \&$ \\ ANTONIO ROMALINO SANTOS FRAGOSO-CESAR ${ }^{2}$
}

\begin{abstract}
Resumo O objetivo do presente trabalho é apresentar os dados obtidos nos estudos de proveniência e paleocorrentes realizados em unidades fluviais do Grupo Maricá (Ediacarano do Rio Grande do Sul). Estas análises permitiram inferir que as áreas fontes destes depósitos eram caracterizadas principalmente por rochas de composição granítica (álcalis feldspato granitos e granitos com granada) e tonalíticas, além de quartzitos, quartzo de veio e rochas vulcânicas. Os estudos geocronológicos realizados em amostras de calhaus revelaram que estas rochas fontes apresentam idades de cristalização entre o Arqueano e o Paleoproterozóico. De acordo com as medidas de paleocorrentes, a área fonte situava-se a sul, indicando, juntamente com os dados de proveniência, que esta correspondia ao Cráton Rio de La Plata. As unidades associadas às atividades orogênicas brasilianas na região (Terreno Rio Vacacaí e Cinturão Dom Feliciano) se comportaram como embasamento da bacia, sem contribuição reconhecida como área fonte. Estes elementos, aliados à maturidade textural observada e às características litofaciológicas do Grupo Marica reafirmam a independência tectônica de sua bacia em relação ao Ciclo Brasiliano, e sugerem um ambiente intracratônico durante a acumulação de seus depósitos.
\end{abstract}

Palavras-Chave: Grupo Maricá, Bacia do Camaquã, proveniência, paleocorrentes, Ediacarano

\begin{abstract}
PROVENANCE ANALYSES, UIPb SOURCE AREA AGE, TEXTURAL MATURITY AND PALEOCURRENTS OF MARICA GROUP (EDIACARAN OF RIO GRANDE DO SUL STATE) The aim of this work is summarize the results of provenance and paleocurrents analyses of Maricá group (Ediacaran of Rio Grande do Sul state). These analyses show that source areas were composed of granite rocks (alkalis feldspar granite and granite with garnet) tonalities and, in minor proportion, quartzite, quartz vein and volcanic rocks. According to geochronological analyses of cobble samples, these source areas developed during Archean and Paleoproterozoic. The provenance and paleocurrents suggest that Rio de La Plata Craton rocks were the most important source area, and the Rio Vacacaí terrain and Dom Feliciano belt were the basements units of the Camaquã basin during the Maricá group evolution. These evidences, the high textural maturity and facies analyses suggest that Maricá group developed in an intracratonic basin with no related to the Brasiliano Orogeny.
\end{abstract}

Keywords: Maricá group, Camaquã basin, provenance, paleocurrents, Ediacaran

INTRODUÇÃO O Grupo Maricá —reclassificação e subdivisão da Formação Maricá de Leinz et al. (1941) proposta por Pelosi \& Fragoso-Cesar (2003) - é a primeira unidade de cobertura não-metamórfica do Rio Grande do Sul (Figs. 1 e 2), constituindo a base do Supergrupo Camaquã (sensu FragosoCesar et al. 2003, com modificações propostas em Janikian et al. 2003 e Fambrini 2003), entidade estratigráfica maior que reúne todos os depósitos da Bacia do Camaquã.

Os trabalhos acessíveis sobre o Grupo Maricá registram o conhecimento geológico acumulado em mapeamentos regionais de pequena escala (e.g. Leinz et al. 1941, Ribeiro et al.1966, Tessari \& Giffoni 1970) e em revisões regionais (e.g. Robertson 1966, Ribeiro 1983, Fragoso-Cesar et al. 1985, Paim 1994). Estudos detalhados acompanhados por mapeamento 1:50 000, excetuando o da CPRM na Folha Passo do Salsinho (Porcher et al. 1995), devem-se a estudantes de graduação dos cursos de geologia da UFRGS e UNISINOS e mantidos inéditos, não tendo sido analisados na pesquisa bibliográfica que antecedeu o presente texto.

Com o intuito de ampliar os conhecimentos sobre este tema, o Grupo Maricá vem sendo, ao longo do último qüinqüênio, objeto de estudos intensivos envolvendo: (i) mapeamento geológico na escala 1:50 000 de todas as suas exposições acompanhado por (ii) análise de fácies, associações de fácies e sistemas deposicionais; (iii) análise de proveniência, paleocorrentes e maturidade textural em depósitos de arenitos conglomeráticos e conglomerados fluviais; (iv) revisão litoestratigráfica e (v) paleogeográfica. Destes estudos, parte está contida em Pelosi (2001, 2005) e Pelosi \& Fragoso-Cesar (2003).

Na presente nota são discutidos os dados coletados em 12 estações de análise de proveniência (sendo 6 acompanhadas por análises de maturidade) e 10 de paleocorrentes, regionalmente distribuídas para permitir uma avaliação geral da drenagem das unidades fluviais e das fontes que alimentaram a bacia do Grupo Maricá, fundamental para a elaboração de sua paleogeografia.

Os resultados obtidos levantaram a necessidade de estudos geocronológicos em clastos representativos das principais áreas fontes para caracterizar suas idades e, juntamente com os dados de paleocorrentes e de maturidade, o contexto tectônico durante a evolução do Grupo Maricá. Com este objetivo foram extraídos zircões e monazitas de clastos selecionados e enviados para análises radiométricas pelo método U-Pb em zircões no Laboratório de Geocronologia do Instituto de Geociências da Universidade de Brasília e, em monazitas, no Centro de Pesquisas Geocronológicas da Universidade de São Paulo.

A BACIA DO CAMAQUÃ A entidade deposicional da porção centro-sul do Rio Grande do Sul (RS) que compreende os espessos $(>10 \mathrm{~km})$ depósitos terrígenos e vulcanogênicos do Supergrupo Camaquã (Ediacarano / Eocambriano) vem sendo, 
desde Carvalho (1932), designada como Bacia do Camaquã, em referência ao rio que corta transversalmente seus depósitos. Situa-se sobre as rochas de embasamento pré-cambriano deste estado, estando compartimentada em três sub-bacias de direção NNE-SSW separadas pelos altos internos de Caçapava do Sul e da Serra das Encantadas, denominadas de Sub-Bacia Camaquã Ocidental, Sub-Bacia Camaquã Central e Sub-Bacia Camaquã Oriental (Fig. 1).

Além de (i) o Grupo Maricá, cujas exposições estão restritas à Sub-Bacia Camaquã Ocidental, o Supergrupo Camaquã também contém (ii) o Grupo Bom Jardim (sensu Janikian et al. 2003), vulcano-sedimentar e aflorante nas sub-bacias Camaquã Ocidental e Camaquã Central; (iii) a Formação Acampamento Velho (sensu Ribeiro \& Fantinel 1978), vulcanogênica e bem representada na Sub-Bacia Camaquã Ocidental; (iv) o Grupo Santa Bárbara (sensu Fambrini 2003), terrígeno e aflorante em todas sub-bacias; (v) o Grupo Guaritas (sensu Almeida 2005), terrígeno e dominando a Sub-Bacia Camaquã Central, e (vi) a Suíte Rodeio Velho composta por corpos tabulares básicos que intrudem, preferencialmente, o Grupo Guaritas.

Os eventos tectônicos que afetam o Supergrupo Camaquãtanto os sin- como os pós-deposicionais - estão condicionados à reativação de falhas antigas geradas durante a evolução do Ciclo Brasiliano no RS, principalmente as de direção NNE-SSW e WNW-ESE. Entre estas, destacam-se, respectivamente, as zonas de falhas Tapera Emiliano e Ibaré, que deformaram importantes segmentos da bacia, cujos efeitos incluem a verticalização de blocos de largura quilométrica incluindo sua unidade terrígena mais jovem, o Grupo Guaritas (Almeida 2005). A influência destas direções gerais de falhas na deformação rúptil que afeta o Grupo Maricá está destacada na Fig. 2.

São reconhecidos registros de eventos tectônicos distensivos sin-deposicionais em unidades do Supergrupo Camaquã que sucederam à deposição do Grupo Maricá (Fragoso-Cesar et al. 2001, Almeida 2005). A importância estratigráfica destes registros — principalmente falhas sin-sedimentares e sismitosmaterializa-se nos contatos entre as unidades litoestratigráficas da Bacia do Camaquã, como regra marcados por discordâncias angulares de baixo a muito baixo ângulo, apenas localmente atingindo ângulos elevados (e.g. $65^{\circ}$ entre os grupos Santa Bárbara e Guaritas junto às Minas do Camaquã). A Fig. 1 evidencia, por um lado, que as unidades da Bacia do Camaquã ocorrem sobre todas as estruturas geotectônicas individualizadas pelo Ciclo Brasiliano no RS (Fragoso-Cesar 1991): (i) no Cráton do Rio de La Plata, pela Formação Acampamento Velho no Platô Taquarembó (região de Dom Pedrito); (ii) no Cinturão Dom Feliciano, pelos grupos Santa Bárbara e Guaritas e intrusões da Suíte Rodeio Velho, e, (iii) no Terreno Rio Vacacaí, por quase toda coluna estratigráfica do Supergrupo Camaquã.

Por outro lado, a única unidade que cobre apenas uma estrutura brasiliana é o Grupo Maricá, restrito a ocorrências sobre o Terreno Rio Vacacaí, exceto a de Três Estradas, situada na Zona de Falhas Ibaré, limite tectônico entre este terreno e o Cráton Rio de La Plata.

O GRUPO MARICÁ A divisão estratigráfica proposta por Pelosi \& Fragoso-Cesar (2003) para o Grupo Maricá foi aplicada em todas as suas áreas de exposição (Fig. 2), mostrandose consistente e apresentando, como regra, maiores variações laterais de espessura do que de fácies. As unidades mapeadas são designadas, da base para o topo, como formações Passo da Promessa, São Rafael e Arroio América (Fig. 3).

A tectônica pós-deposicional que afeta estas unidades é de caráter rúptil reativando falhas anteriores e basculando suas camadas (mergulhos dominantemente moderados; sub-verticais apenas em trechos da ocorrência de Lavras do Sul e Três Estradas, afetada por reativações da Zona de Falha Ibaré; vide Fig. 2).

O ambiente deposicional das formações Passo da Promessa e Arroio América é registrado em espessos depósitos de arenitos e conglomerados de sistemas fluviais entrelaçados — desde em torno de $900 \mathrm{~m}$ até cerca de $500 \mathrm{~m}$, e de $500 \mathrm{~m}$ a $300 \mathrm{~m}$, respectivamente, ambos acunhando para norte (Fig. 3).

Sugestões de ambiente marinho para a unidade de arenitos e pelitos do Grupo Maricá (Formação São Rafael) são comuns na literatura geológica do RS (Ribeiro et al. 1966, Ribeiro 1983, Fragoso-Cesar et al. 1985, Lavina et al. 1985, Leites et al. 1990, Paim et al. 1995). A Formação São Rafael é composta basicamente por depósitos de plataforma sob a ação de ondas, com depósitos de costa afora (turbiditos) intercalados predominando para norte (Fig. 3). Esta sucessão marinha do Grupo Maricá espessa-se para norte, desde em torno de $600 \mathrm{~m}$ na região de Lavras do Sul até cerca de $900 \mathrm{~m}$ na região do Passo do Salsinho (Fig. 3).

O Grupo Maricá desenvolveu-se durante o Ediacarano, considerando-se os dados geocronológicos disponíveis sobre o Granito Lavras do Sul, que o intrude, e sobre o Terreno Rio Vacacaí, que constitui seu embasamento. Os estudos neste terreno e granitóides associados apontam idades de $750 \mathrm{Ma}$ a $630 \mathrm{Ma}$ entre as mais jovens (Soliani Jr. 1986, Machado et al. 1990, Chemale Jr. et al. 1994, Babinski et al. 1996). As idades U-Pb SHRIMP em zircões extraídos do Granito Lavras situam-se entre $600 \mathrm{Ma}$ e 580 Ma (Leite 1995, Remus et al. 1997, Mexias 2000 apud Bongiolo et al. 2003). Embora não se tenha uma idade definida para a deposição do Grupo Maricá, esta possivelmente ocorreu entre $630 \mathrm{Ma}$ e $600 \mathrm{Ma}$.

ANÁLISE DE PROVENIÊNCIA O reconhecimento da natureza da área fonte de uma bacia é fundamental para a compreensão da evolução tectônica e paleogeográfica de seus depósitos. A composição, dimensão e forma dos detritos de uma unidade sedimentar estão diretamente relacionadas às condições climáticas e tectônicas atuantes durante o transporte, deposição e soterramento (Miall 1990). Esta premissa revela a necessidade de estudo da proveniência dos fragmentos que constituem uma sucessão sedimentar, pois este fornece elementos de grande importância para a reconstrução paleogeográfica de uma bacia e suas áreas adjacentes. Da mesma forma, o estudo de paleocorrentes adiciona informações de grande utilidade na análise da bacia, incluindo a localização das áreas fontes, a direção do transporte e a interpretação de sistemas deposicionais atuantes.

A análise de proveniência foi precedida de trabalhos de mapeamento litofaciológico e análises de fácies e sistemas deposicionais. Este levantamento permitiu uma avaliação das melhores áreas para amostragem, situadas nas unidades de origem fluvial (formações Passo da Promessa e Arroio América), pois as características litofaciológicas destas, onde seixos e calhaus são relativamente comuns, possibilitam este tipo de análise em campo.

Na análise de proveniência realizou-se a identificação, descrição e contagem de seixos e calhaus da fácies de arenitos conglomeráticos e de conglomerados, a amostragem para estudos laboratoriais (petrográficos e geocronológicos) e a análise estatística dos dados.

Nas estações amostradas, sobre os clastos foram anotados: (i) composição; (ii) granulometria; (iii) grau de arredondamento e esfericidade; e (iv) seleção granulométrica.

Nestas procurou-se computar 100 fragmentos de $\varnothing>3 \mathrm{~cm}$ que, segundo Ibbeken \& Schleyer (1991), fornecem dados satisfatórios para análises estatísticas. No total foram computados 1400 fragmentos em 12 estações de amostragem espalhadas em todas as áreas de ocorrência das formações Passo da Promessa e Arroio América. 


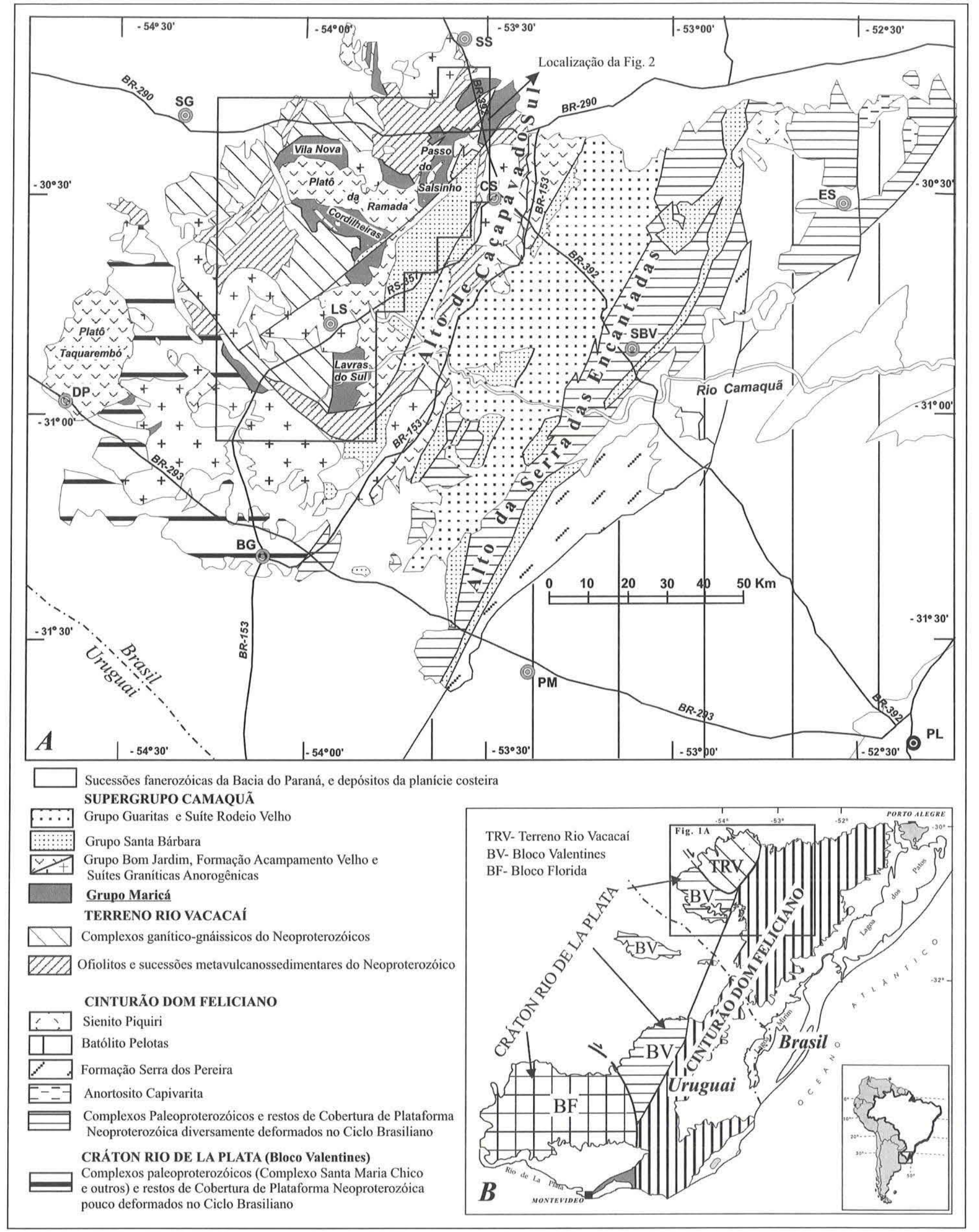

Figura 1-A Mapa geológico da porção centro-sul do Rio Grande do Sul, com destaque para as unidades que constituem o Supergrupo Camaquã e seu embasamento plutônico-metamórfico. Cidades: BG-Bagé, CS - Caçapava do Sul, DP - Dom Pedrito, ES - Encruzilhada do Sul, LS-Lavras do Sul, PL-Pelotas, PM-Pinheiro Machado, SBV-Santana da Boa Vista, SG - São Gabriel, SS-São Sepé. B Localização do mapa geológico no Pré-Cambriano do RS e Uruguai. 
Para a análise estatística, foram elaborados gráficos de proveniência apresentando a percentagem da litologia dos clastos encontrados em cada unidade. Os dados de maturidade textural contribuíram para caracterizar o grau de retrabalhamento refletindo a distância da área fonte.
Além do levantamento dos dados em campo, foram efetuados estudos petrográficos com o objetivo de caracterizar a composição dos fragmentos que constituem as unidades do Grupo Maricá. Neste estudo foram realizadas análises petrográficas nos arenitos e nos seixos e calhaus.

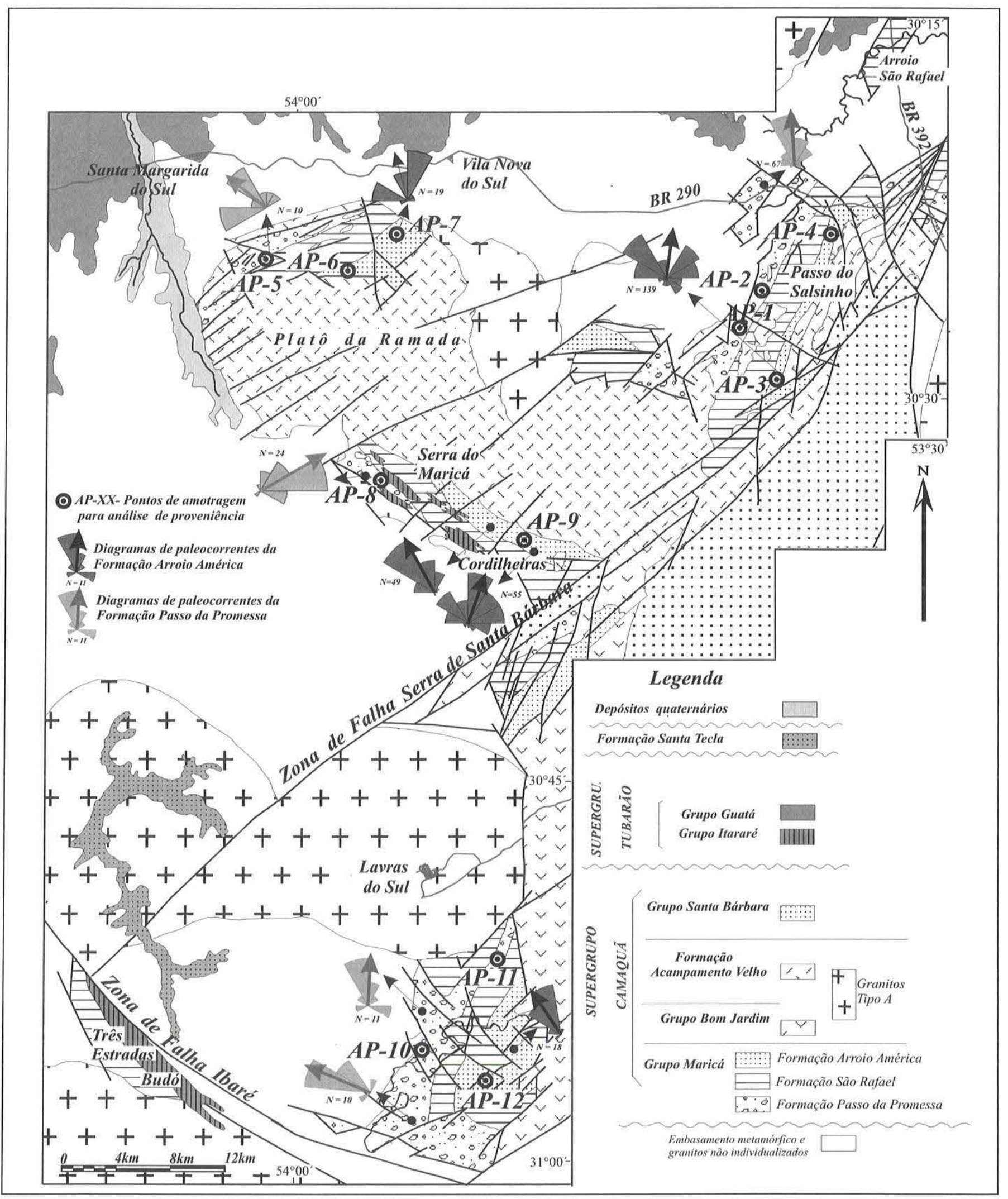

Figura 2- Mapa Geológico das ocorrências do Grupo Maricá no Rio Grande do Sul, com destaque para os locais de amostragem das análises de proveniência e paleocorrentes (localização na Fig.1). 
Resultados da análise de proveniência realizada em campo Os dados de proveniência, obtidos através da contagem de seixos e calhaus em afloramentos de arenitos conglomeráticos e conglomerados das formações Passo da Promessa e Arroio América, foram reunidos em gráficos para uma análise estatística dos dados e para a visualização da variação da composição das áreas fontes entre as regiões e unidades investigadas. Estes gráficos encontram-se expostos na figura 4.

Destaca-se nestes gráficos que os litotipos tabelados são diversos, porém com predomínio de fragmentos de alta resistência física à erosão, tais como granitos, riolitos, quartzitos e quartzo leitoso - embora os litotipos quartzosos sejam os mais resistentes, sua participação subordinada supervaloriza a contribuição granítica e riolítica. A composição dos fragmentos indica que a área fonte era predominantemente composta por rochas de com- posição granítica (de $65 \%$ a $90 \%$, Fig. 4), incluindo granitos maciços, foliados e milonitos quartzo-feldspáticos. A segunda maior concentração de seixos e calhaus é de quartzitos e de quartzo de veio ( $>10 \%$, não ultrapassando $24 \%$ ); assim como as rochas graníticas, estas também ocorrem em todas as estações de amostragem (Fig. 4). Clastos de rochas vulcânicas ácidas são encontrados em proporções menores, e apenas em determinados pontos de amostragem. Em poucas estações foram encontrados fragmentos de rochas sedimentares (arenitos e siltitos), rochas metabásicas e andesitos, nenhum destes litotipos ultrapassando $5 \%$ do total computado.

Dentre as rochas graníticas, distinguimos três classes descritivas em campo: granitos maciços, granitos foliados e milonitos quartzo-feldspáticos (Fig. 4). Ambas as classes ocorrem em proporções variadas nas formações Passo da Promessa e Arroio

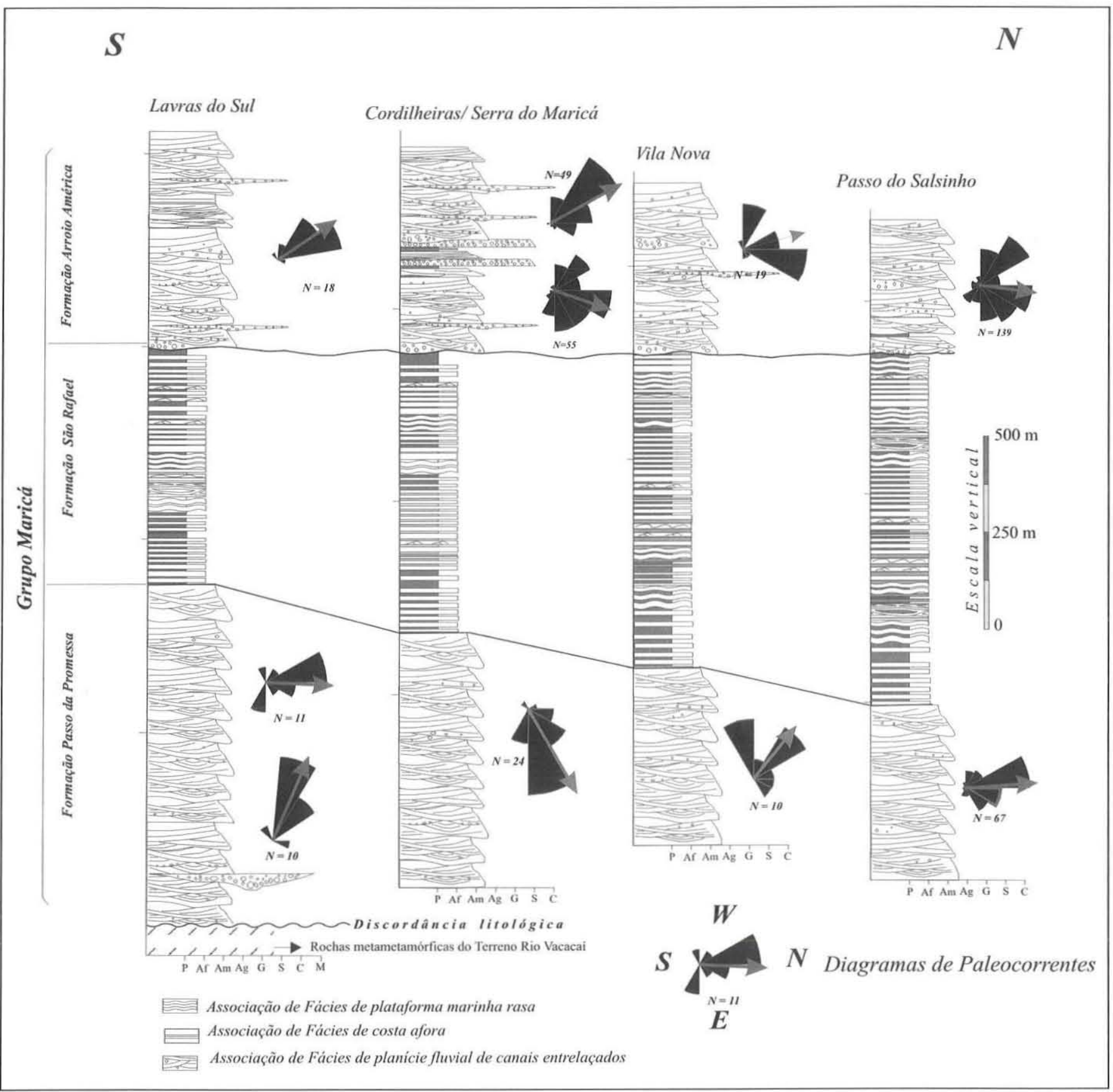

Figura 3- Seções compostas do Grupo Maricá em suas principais áreas de ocorrência. As rosetas de paleocorrentes estão rotacionadas em $90^{\circ}$ para que o Norte coincida com o da seção. 

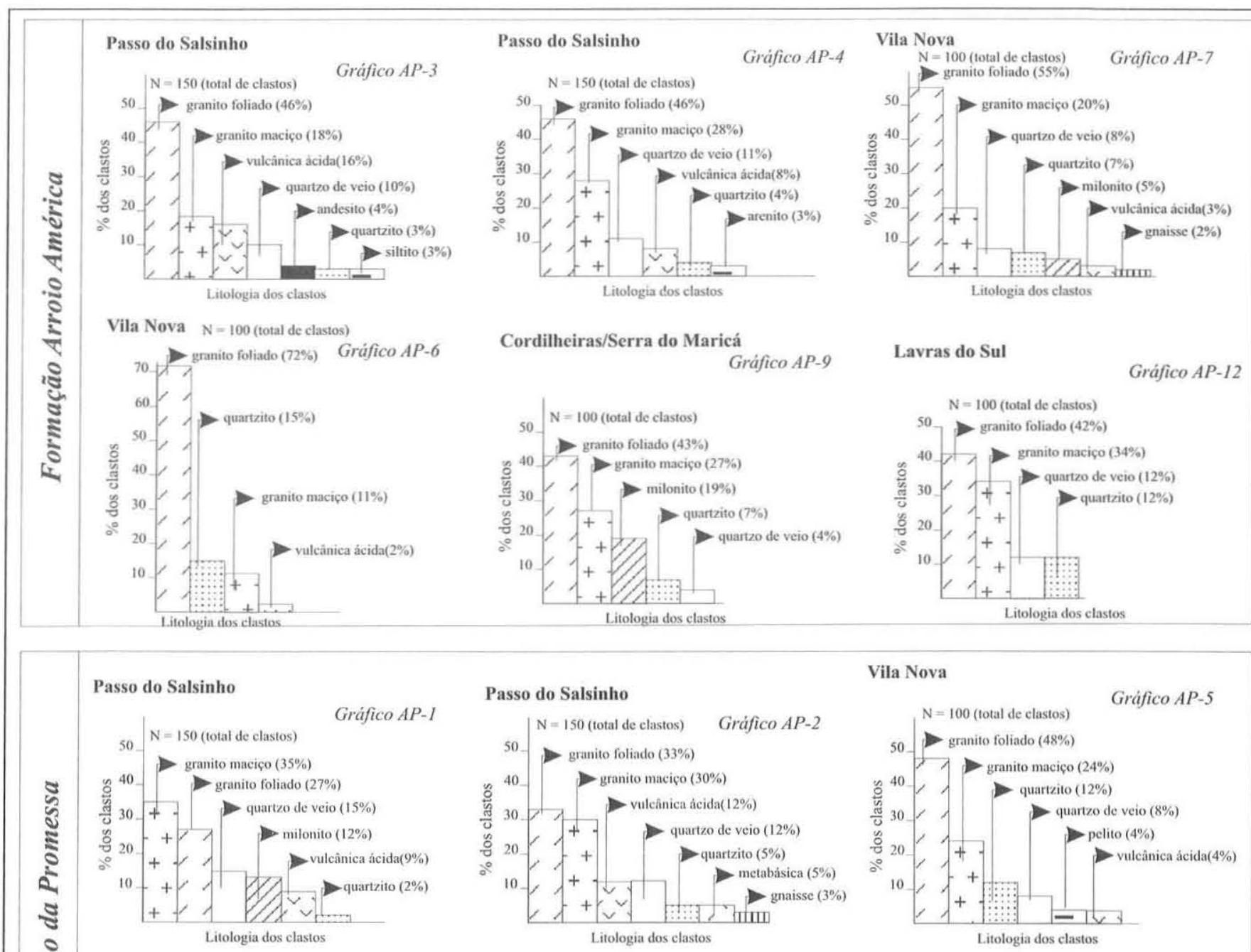

\section{Passo do Salsinho}

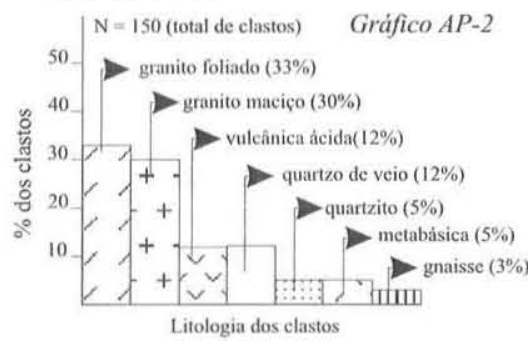

Lavras do Sul

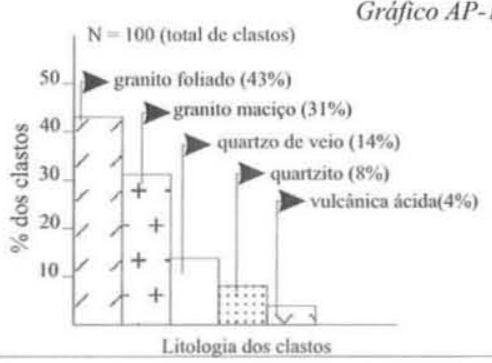

Vila Nova

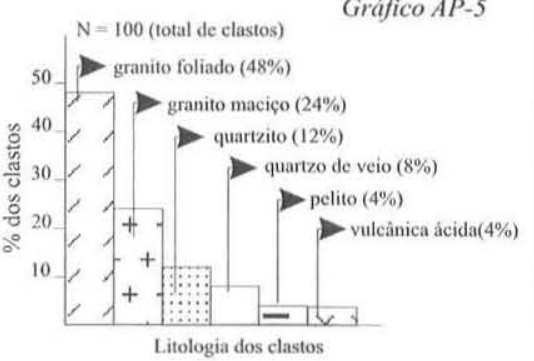

Lavras do Sul

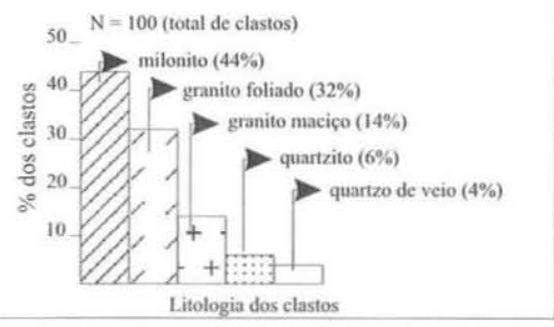

Figura 4- Gráficos de proveniência obtidos nas formações Passo da Promessa e Arroio América (ver localização dos locais de amostragem na Fig. 2).

América, mas os granitos foliados quase sempre predominam sobre os maciços e os milonitos.

Em amostra de mão, os granitos maciços são róseos, leucocráticos, com granulação variando de fina a média, localmente com fenocristais esparsos na matriz isótropa. A classe de granitos foliados é caracterizada por rochas quartzo-feldspáticas, leucocráticas de coloração rósea e cinzenta, com foliação de natureza protomilonítica ou ígnea e com granulação de fina a média. Estes litotipos representam às principais áreas fontes do Grupo Maricá, pois seus fragmentos são encontrados em todos os arenitos conglomeráticos e conglomerados das formações Passo da Promessa e Arroio América. Outra fonte importante, também de composição granítica, corresponde aos clastos de milonitos quartzo-feldspáticos.
Durante a análise em campo, agrupamos, no conjunto de rochas vulcânicas ácidas, os riolitos de matriz afanítica com fenocristais de quartzo bipiramidado e de plagioclásio euédrico e rochas piroclásticas ácidas (brechas e tufos). Na unidade superior (Formação Arroio América), além de rochas vulcânicas ácidas também foram reconhecidos, em uma estação (AP-3) na região do Passo do Salsinho, cerca de $4 \%$ (Fig. 4) de clastos de andesitos.

Estudos petrográficos dos arenitos do Grupo Marica também revelaram uma proveniência de áreas fontes graníticas, metamórficas de alto grau, milonítica e de rochas vulcânicas ácidas e intermediárias (Pelosi 2005).

Petrografia dos seixos e calhaus Os resultados apresentados no item anterior permitiram uma visualização das principais 
áreas fontes que alimentaram os depósitos do Grupo Maricá. Neste, apresentaremos a descrição do estudo petrográfico dos seixos e calhaus coletados em campo, preliminarmente exposta em Morenghi et al. (2002) e Pelosi et al. (2002). Esta descrição microscópica permitiu uma melhor caracterização da composição das áreas fontes. Para uma comparação com os gráficos obtidos na análise em campo, a descrição petrográfica seguirá uma ordem de grandeza iniciando-se com a caracterização petrográfica dos litotipos mais comuns (granitos foliados e maciços) e finalizando com a descrição das rochas de menor percentagem de ocorrência (milonitos, quartzitos e rochas vulcânicas).

ROCHAS GRANITICAS FOLIADAS A análise petrográfica revelou três litotipos que constituem a classe de granitos foliados: (i) mesopertita granitos, (ii) granitos milonitizados com granada e (iii) metatonalitos leucocráticos. Conforme visto pela contagem de clastos em campo, estas rochas representam às principais áreas fontes do Grupo Maricá.
Os mesopertita granitos são caracterizados por cristais equigranulares menores que $1 \mathrm{~mm}$ (Fig. 5A), cujas orientações geram uma estrutura granular foliada, provavelmente por fluxo ígneo, sem evidência de deformação dos minerais (Fig 5A). Estes granitos são compostos por: quartzo $(\sim 50 \%)$, mesopertitas $(\sim 20 \%)$, microclínio $(\sim 20 \%)$, plagioclásio $(\sim 5 \%)$ e mirmequita, muscovita e zircão como acessórios $(<5 \%)$. Esta composição cai no campo limítrofe entre os álcalis feldspato granitos e os sienogranitos. Os minerais de quartzo encontram-se em bolsões e veios imersos na matriz de feldspato alcalino (Fig 5A). Não foram encontrados minerais máficos nestas rochas.

Os granitos milonitizados com granada são compostos por: quartzo (45\%), plagioclásio sódico $(15 \%)$, pertitas $(\sim 15 \%)$, microclínio $(\sim 10 \%)$, granada $(\sim 3 \%)$ e andaluzita, muscovita e opa$\cos (<2 \%)$. A textura é porfiroclástica fina inequigranular; a estrutura, protomilonítica, marcada pela deformação dos porfiroclastos de feldspato e de minerais de quartzo. A granada ocorre na forma idiomórfica subeudral, fraturada e orientada segundo
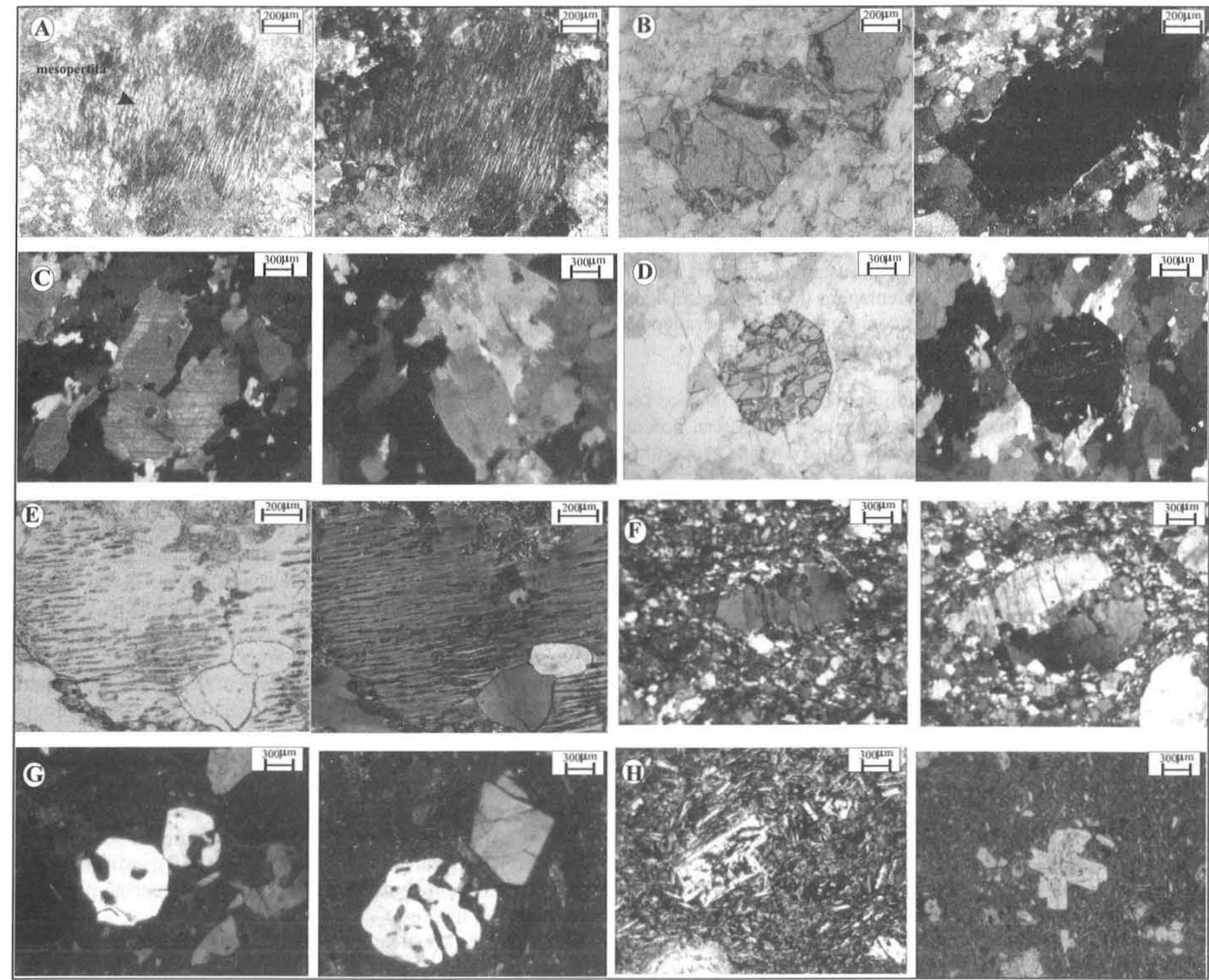

Figura 5- Fotomicrografias de lâminas de seixos e calhaus das formações Passo da Promessa e Arroio América. A- Aspecto geral dos álcalis feldspato granitos, compostos essencialmente por uma matriz feldspática (pertitas e microclínio) e por micro-veios de quartzo que dão à rocha um aspecto foliado. B-Granadas idiomórficas subeudrais fraturadas. C- Granada-muscovita granito, destacando muscovitas subédricas e euédricas. D-Granada muscovita granito com destaque para uma granada euédrica. E- Detalhe de uma pertita de um álcalis feldspato granito. F- Tonalito milonitico, destacando "augen" de plagioclásio orientado segundo foliação milonitica. G-Riolitos com cristais de quartzo bipiramidado corroidos imersos em uma matriz microcristalina. H-Andesitos com matriz fina com plagioclásio ripiforme e fenocristais de plagioclásio euédricos e com germinação cruzada. 
a foliação (Fig. 5B).

As rochas de composição tonalítica apresentam uma textura granoblástica média com cristais maiores que $1 \mathrm{~mm}$. A estrutura é identificada por uma suave orientação dos minerais que dão à rocha um aspecto foliado. Desta forma, estas rochas podem ser classificadas como metatonalitos. Os minerais essenciais são o plagioclásio An20-oligoclásio (45\%) e o quartzo (40\%). Feldspato potássico, titanita e óxido de ferro aparecem como acessórios $(<5 \%$ ); epídoto, clinozoizita e zircão, como traços.

ROCHAS GRANÍTICAS MACIÇAS A classe de rochas graníticas maciças é muito semelhante à de rochas graníticas foliadas. O estudo petrográfico revelou três grupamentos análogos de rochas: (i) granada-muscovita granito, (ii) tonalito e (iii) álcali feldspato granito.

Os granada-muscovita granitos são classificados como rochas maciças hipidiomórficas com granulação variando de 0,5 a $2 \mathrm{~mm}$. A análise modal indicou a seguinte composição: plagioclásio sódico $(\sim \mathrm{An} 10, \sim 50 \%)$, quartzo $(\sim 30 \%)$, muscovita $(\sim 15 \%)$, granada e apatita como acessórios $(<5 \%)$. A muscovita placóide subédrica e euédrica esta disseminada na rocha, fazendo contato com todos os minerais (Fig.5C). A granada aparece euédrica e com inclusões de quartzo (Fig. 5D).

As rochas tonalíticas são compostas por quartzo $(\sim 45 \%)$, plagioclásio sódico ( $\sim 45 \%)$, muscovita e microclínio $(\sim 10 \%)$. A textura é granítica com cristais de 0,1 a $0,8 \mathrm{~mm}$. Os álcalis feldspato granitos (Fig. 5E) caracterizam-se por uma textura equigranular média, compostos por quartzo $(\sim 45 \%)$, pertita $(\sim 25 \%)$, microclínio $(\sim 15 \%)$, plagioclásio $(\sim 5 \%)$, muscovita, opacos, zircão e epidoto $(<5 \%)$. A elevada porcentagem de minerais félsicos permite classificar estes granitos como granitos leucocráticos e hololeucocráticos, bem como denomina-los de aplitos.

ROCHAS MILONÍTICAS Os milonitos foram analisados separadamente das rochas graníticas maciças e foliadas, porém suas composições não se diferenciam muito daquelas encontradas nas rochas acima descritas. Dois tipos básicos foram identificados; milonitos tonalíticos e graníticos.

Os milonitos tonalíticos são caracterizados por plagioclásio $(\sim 55 \%)$, quartzo $(\sim 35 \%)$, microclínio $(\sim 5 \%)$, biotita, opacos, zircão e clorita $(<5 \%)$. Os cristais de quartzo aparecem fraturados e deformados, envolvendo fenocristais de feldspatos que se encontram rotacionados pela foliação milonítica (Fig. 5F). Os milonitos graníticos contêm foliação milonítica que deforma todos os cristais. São formados por quartzo $(\sim 30 \%)$, microclínio $(\sim 35 \%)$, plagioclásio $(\sim 25 \%)$, muscovita $(\sim 5 \%)$ e opacos $(\sim 5 \%)$. O quartzo e o feldspato potássico aparecem bastante estirados; o plagioclásio, granular fino, ocorre em lentes e corpos alongados acompanhando a foliação principal.

QUARTZITOS Dois tipos de quartzitos foram identificados: (i) quartzitos feldspáticos e (ii) quartzito. Os quartzitos feldspáticos são compostos por quartzo $(\sim 80 \%)$, ortoclásio $(\sim 20 \%)$, muscovita e opacos como traços. A textura é granoblástica fina e a estrutura é maciça. Os quartzitos são compostos essencialmente por quartzo $(\sim 95 \%)$; como acessórios $(<5 \%)$ incluem limonita, sericita, turmalina, biotita e zircão. A textura é granoblástica eqüigranular; a estrutura, maciça a laminada.

ROCHAS VULCANNICAS O estudo petrográfico destes fragmentos permitiu o reconhecimento de dois litotipos principais: (i) riolitos e (ii) andesitos. Os riolitos ocorrem em todas as áreas de exposição do Grupo Maricá, porém os andesitos, além de raros, são restritos à Formação Arroio América.
Os riolitos apresentam textura porfirítica com matriz holocristalina muito fina e estrutura maciça (Fig. 5G). A rocha é composta por fenocristais $(\sim 35 \%)$, matriz $(\sim 55 \%)$ e autólitos $(\sim 10 \%)$. A mineralogia é caracterizada por quartzo $(\sim 30 \%)$, oligoclásio $(\sim 30 \%)$, ortoclásio pertita $(\sim 30 \%)$ e fragmentos autolíticos $(\sim 10 \%)$, além de biotita e opacos como acessórios. A matriz microcristalina tem composição félsica. Os fenocristais são predominantemente de quartzo e feldspato. O quartzo aparece corroído e bipiramidal (Fig. 5G). O quartzo vulcânico possui inclusões da matriz. Os grãos de oligoclásio contêm uma alteração para sericita, preservando a forma euédrica original, porém com as bordas desgastadas. O ortoclásio é anédrico com alteração de cor marrom (argilo mineral).

Os andesitos são caracterizados por textura porfirítica, estrutura maciça, onde a matriz constitui $80 \%$ da rocha, fenocristais $\sim 10 \%$ e autólitos $\sim 10 \%$. A mineralogia da rocha é de plagioclásio $(\sim 30 \%)$, opacos $(\sim 40 \%)$ e minerais máficos $(\sim 30 \%)$. Os fenocristais de plagioclásio (An-25\%) variam de euédricos a subéudricos; quando muito finos, com formato acicular; os maiores com hábito ripiforme (Fig. $5 \mathrm{H}$ ). As rochas apresentam um elevado grau de alteração, onde a maior parte dos fenocristais de minerais "máficos" encontram-se substituídos por filossilicatos e ou carbonatos.

ANÁLISE DE PALEOCORRENTES A análise de paleocorrentes foi realizada concomitantemente à de proveniência. Os dados de direção de fluxo foram obtidos em planos de estratificações cruzadas acanaladas de médio porte e tabulares (rank 5 de Miall 1974), por serem as estruturas disponíveis na região - embora sejam abundantes os afloramentos de arenitos fluviais, o freqüente aspecto maciço que mascara as estruturas indicativas de fluxo sedimentar limita a amostragem de medidas. Apesar das restrições, as medidas obtidas fornecem dados estatisticamente satisfatórios conforme descrito na literatura (Miall 1974, 1990, Poter \& Pettijohn 1977, Tucker 1993). No total foram obtidas 402 medidas em 11 estações de amostragem, que em laboratório foram reunidas em gráficos de paleocorrentes do tipo roseta para cada estação amostrada.

Devido à forte inclinação das camadas, as medidas tiveram de ser corrigidas. Esta correção foi realizada utilizando-se o programa PALEOCOR desenvolvido por Almeida (2001), que corrige o efeito tectônico e horizontaliza as camadas, além de calcular o vetor médio e o fator de consistência. Os dados corrigidos foram plotados em gráficos do tipo roseta (Fig. 2 e 3).

Estudos anteriores de paleocorrentes no Grupo Maricá são restritos aos trabalhos de Paim et al. (1995), Paim (1994) e Porcher et al. (1995), que apontam sentido de transporte para quadrantes orientais, variáveis de E para E-SE. No entanto, os dados aqui obtidos indicam que o transporte foi para os quadrantes setentrionais, entre NW e NE, preferencialmente para norte. Os vetores médios para a Formação Passo da Promessa apontam um transporte sedimentar de sul para norte. Os dados obtidos na Formação Arroio América são muito semelhantes aos encontrados na unidade inferior (Fig. 2 e 3), indicando também um transporte para norte com alguma dispersão para leste e sudoeste (Fig. 2 e 3 ).

Os dados de paleocorrentes obtidos indicam que as áreas fontes situavam-se predominantemente no sul, podendo haver contribuição dos quadrantes ocidentais e orientais. Estes dados sugerem inclinação da bacia segundo a direção N-S, onde os rios tendem a correr para os quadrantes setentrionais.

ANÁLISE DA MATURIDADE TEXTURAL Em 6 estações de amostragem de proveniência em campo foram também anotados dados sobre a maturidade textural dos fragmentos, incluindo forma, arredondamento, esfericidade e dimensão (sele- 
ção granulométrica), seguindo os parâmetros visuais de Powers (1953) e Tucker (1993).

A maturidade textural permite inferir a intensidade dos processos mecânicos durante o transporte e deposição, bem como a composição e distância da área fonte. Fragmentos angulosos, de dimensões elevadas, com má seleção e com baixo grau de arredondamento, sugerem baixas taxas de retrabalhamento e áreas fontes proximais. De forma contrária, fragmentos arredondados, bem selecionados e com esfericidade moderada a alta, indicam altas taxas de retrabalhamento da carga sedimentar e áreas fontes distantes.

Os dados obtidos em campo foram agrupados em gráficos de arredondamento, esfericidade e dimensão dos fragmentos. No total foram realizadas seis estações de amostragem, sendo três na Formação Passo da Promessa e três na Formação Arroio América (Fig.6). Em ambas as unidades salienta-se um elevado grau de maturidade textural.

O grau de arredondamento varia de arredondado a subanguloso, predominando fragmentos subarredondados (Fig. 6). No geral, a forma dos fragmentos é alongada e ovalada, a esfericidade em todas as áreas investigadas é moderada, com proporções razoáveis de esfericidade baixa e alta (Figs. 6 e 7). Como regra os fragmentos são bem selecionados, sendo que predominam clastos da fração calhau entre $6,4 \mathrm{~cm}$ e $15 \mathrm{~cm}$. A fração seixo também ocorre em todas as áreas de exposição das formações Passo da Promessa e Arroio América. Fragmentos maiores que $23 \mathrm{~cm}$ são escassos ocorrendo apenas em algumas localidades (Fig. 6).

ANÁLISE GEOCRONOLÓGICA Após o estudo petrográfico dos seixos e calhaus dos depósitos fluviais das formações Passo da Promessa e Arroio América, foram selecionadas amostras para estudos geocronológicos com objetivo de reconhecer a idade das principais áreas fontes que alimentaram estes depósitos. No total três amostras de calhaus foram analisadas, incluindo uma amostra de álcalis feldspato granito foliado (amostra LV45 A - calhau da Formação Passo da Promessa), um tonalito maciço (amostra LV45 B- calhau da Formação Passo da Promessa) e uma amostra de granito milonitizado com granada (amostra SF 1A- calhau da Formação Arroio América). Conforme exposto no item anterior, estas rochas perfazem de $65 \%$ a $90 \%$ dos fragmentos encontrados nos depósitos fluviais do Grupo Maricá, correspondendo às principais áreas fontes desta unidade, motivo pelo qual foram selecionadas para estudos geocronológicos.

As amostras coletadas foram encaminhadas para procedimentos de separação de zircões e monazitas, incluindo processos de britagem, moagem, concentração em mesa vibratória, separação magnética e em líquidos densos. Os zircões da amostra de tonalito e da amostra de álcali feldspato granito foram analisados pelo método $\mathrm{U} / \mathrm{Pb}$ convencional no Laboratório de Geocronologia do Instituto de Geociências da Universidade de Brasília. As monazitas da amostra de granito milonitizado com granada foram analisadas pelo método $\mathrm{U} / \mathrm{Pb}$ no Centro de Pesquisas Geocronológicas da Universidade de São Paulo.

Os procedimentos analíticos para o método U-Pb na Universidade de Brasília seguem Laux et al. (2004). Os concentrados de zircão foram extraídos a partir de técnicas convencionais gravimétricas (DENSITEST ${ }^{\circledR}$ ) e magnéticas (Frantz isodynamic separator). A separação final foi alcançada usando lupa binocular. Todos os cristais de zircão analisados estão livres de inclusões e fraturas e foram separados da fração menos magnética.

As frações de zircão foram dissolvidas em $\mathrm{HF}$ e $\mathrm{HNO}_{3}$ concentrados ( $\mathrm{HF}: \mathrm{HNO}_{3}=4: 1$ ) usando microcápsulas e bombas do tipo Parr. Uma mistura de traçador (spike) ${ }^{205} \mathrm{~Pb}^{235} \mathrm{U}$ foi utilizada. Para separações químicas aplicou-se resina de troca iônica convencional, com microcolunas de Teflon, seguindo procedimento modificado de Krogh (1973). Pb and U foram deposi- tados juntos em um filamento de $\mathrm{Re}$ com $\mathrm{H}_{3} \mathrm{PO}_{4}$ e Si gel. Para leitura foi utilizado um espectrômetro de massa Finnigan MAT262 com multi-coletor e equipado com uma multiplicadora de elétrons secundários. O branco laboratorial na época das analises era melhor que 20 pg. Os programas PBDAT (Ludwig 1993) e ISOPLOT-Ex (Ludwig 2001) foram usados para o cálculo das idades. Os erros das razões isotópicas são $2 \sigma$. Os dados obtidos encontram-se sintetizados na Tabela 1 .

O diagrama concórdia obtido na amostra de álcali feldspato granito (LV45A) indicam um complexo comportamento dos isótopos de $\mathrm{Pb}$ nos zircões desta rocha, mostrando uma grande dispersão no diagrama. Mais de 10 grãos foram analisados nesta amostra, sendo que todas as análises foram feitas em grãos individuais de zircão, onde foram escolhidos cristais limpos, sem inclusões, prismáticos e alongados. A população de zircões mais jovens sugere uma idade paleoproterozóica, em torno de $2.3 \mathrm{Ga}$ para o seixo de granito estudado, embora com erro elevado é a melhor estimativa da idade de cristalização desta rocha. A maioria dos cristais analisados mostra herança isotópica arqueana ao redor de 2.5 e 2.9 Ga (Fig. 8A). A análise de zircões da amostra de tonalito (LV 45 B) apresentou uma concórdia com idade de $2597 \pm 72 \mathrm{Ma}$ (Fig. 8B) no intercepto superior, apontando também uma idade arqueana para esta rocha. Cristais de zircão apresentando evidências de herança mais antiga em torno de 2.7 Ga não é mostrado na figura, mas estão presentes e as analises foram colocadas na Tabela 1.

As idades dos interceptos inferiores obtidas nestas amostras não têm significado geológico, pois se encontram muito distante dos grãos analisados.

A análise $\mathrm{U} / \mathrm{Pb}$ em monazita realizada na amostra de granito milonitizado com granada (SF 1A) aponta uma idade paleoproterozóica para esta rocha fonte. O diagrama obtido indica uma idade concordante de $2110.9 \pm 4.8 \mathrm{Ma}$ (Fig. 9), interpretada como representativa da época de cristalização destas rochas a partir de fusão crustal.

Estes dados geocronológicos revelam que as áreas fontes do Grupo Maricá, caracterizadas por álcali feldspato granitos, tonalitos e granitos milonitizados com granada apresentam idades de cristalização entre o Arqueano e o Paleoproterozóico, sem evidência de eventos termais neoproterozóicos.

\section{ÁREAS FONTES DO GRUPO MARICÁ E CONSIDERA-} ÇÕES FINAIS Os estudos de proveniência, paleocorrentes, maturidade e idades U/Pb em clastos das formações Passo da Promessa e Arroio América permitem levantar algumas considerações sobre as áreas fontes e condições paleogeográficas atuantes durante o desenvolvimento do Grupo Maricá, ocorrido, possivelmente, entre $630 \mathrm{Ma}$ e $600 \mathrm{Ma}$, considerando a idade mínima de seu embasamento (Terreno Rio Vacacaí) e máxima das intrusões graníticas que o afetam (e.g. Granito Lavras do Sul).

A análise estatística de seixos e calhaus em afloramentos de arenitos conglomeráticos e conglomerados das formações Passo da Promessa e Arroio América evidenciou que estas áreas eram compostas basicamente por rochas de composição granítica, tanto maciça quanto foliada e milonítica, subordinadamente por quartzitos, rochas vulcânicas ácidas e outros litotipos ocasionais, como, em uma estação, andesitos.

O estudo petrográfico e geocronológico dos fragmentos graníticos revelou que suas áreas fontes eram compostas por granitos com granada, tanto milonitizados como sem evidência de deformação, álcalis feldspato granitos, incluindo mesopertitas granitos e leucogranitos, e tonalitos maciços e milonitizados. Estas rochas, com idades do Arqueano e Paleoproterozóico, perfazem até $90 \%$ dos fragmentos encontrados.

A existência de áreas fontes de origem vulcânica evidencia um vulcanismo ácido e intermediário anterior ao magmatismo 


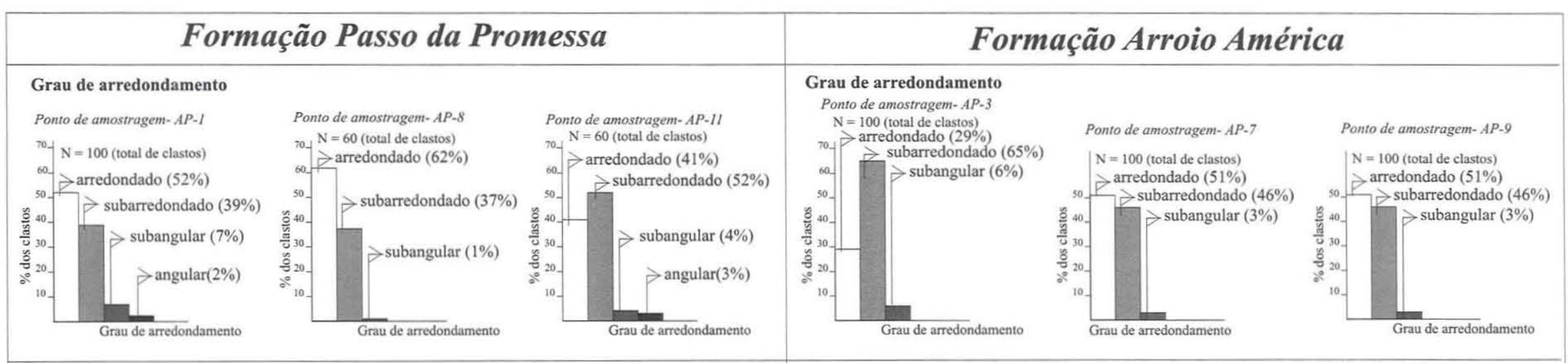

\section{Grau de esfericidade}

Ponto de amostragem- $A P$ -

$N=100$ (total de clastos) $(9 \%)$

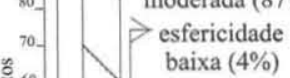

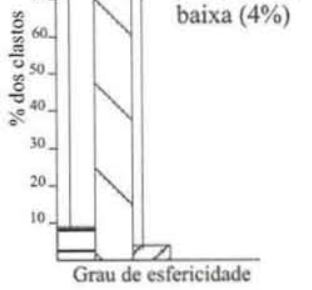

${ }^{90}>\begin{aligned} & \text { esfericidade alta }(9 \%) \\ & >\end{aligned}$

Ponto de amostragem-AP- 8 ${ }^{90}>$ esfericidade alta (23\%)

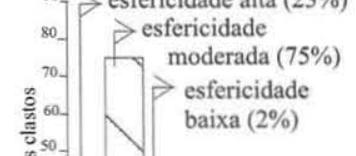

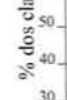
tragem na Fig. 2).

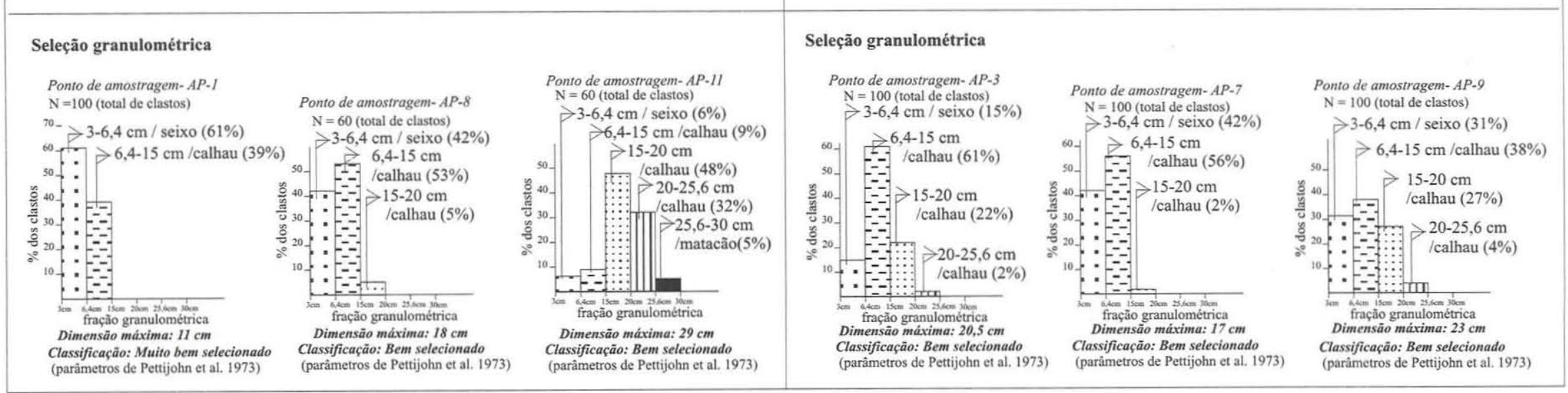

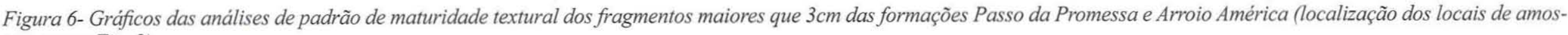
$\mathrm{N}=60$ (total de clastos)

\section{Ponto de amostragem- $A P-I$} $\mathrm{N}=60$ (total de clastos)

$\gg$ esfericidade alta (38\%)

${ }^{70}->$ esfericidade

moderada $(59 \%$
baixa $(3 \%)$
batade

-

-

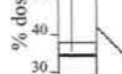

${ }^{20}$

${ }_{10}$

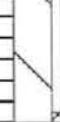

Grau de esfericidade

Ponto de amostragem- $A P-3$

$\mathrm{N}=100$ (total de clastos)

${ }_{90}>$ esfericidade alta (7\%)

Ponto de amostragem-AP-7

80- esfericidade (78\%)

$\mathrm{N}=100$ (total de clastos)

Ponto de amostragem-AP-9

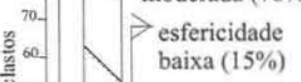

70. $>$ esfericidade

N $=100$ (total de clastos)

Toderada (66\%)

$>$ esfericidade

$\frac{3}{80}$

N

baixa (23\%)

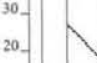

$-$

baixa $(16 \%)$

10

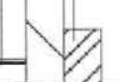

Grau de esfericidade

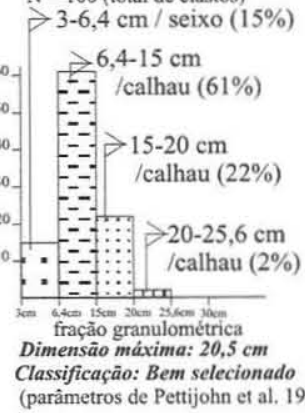

$4,4 \mathrm{~cm} / \operatorname{seixo}(42 \%)$
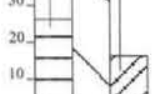

\section{3}

u de esfericidade

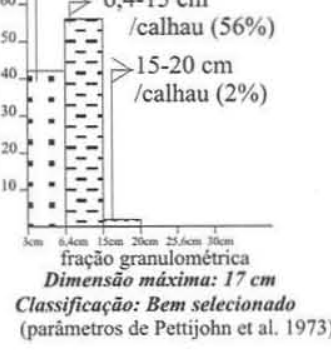

aråmetros de Pettijohn et al. 1973) 

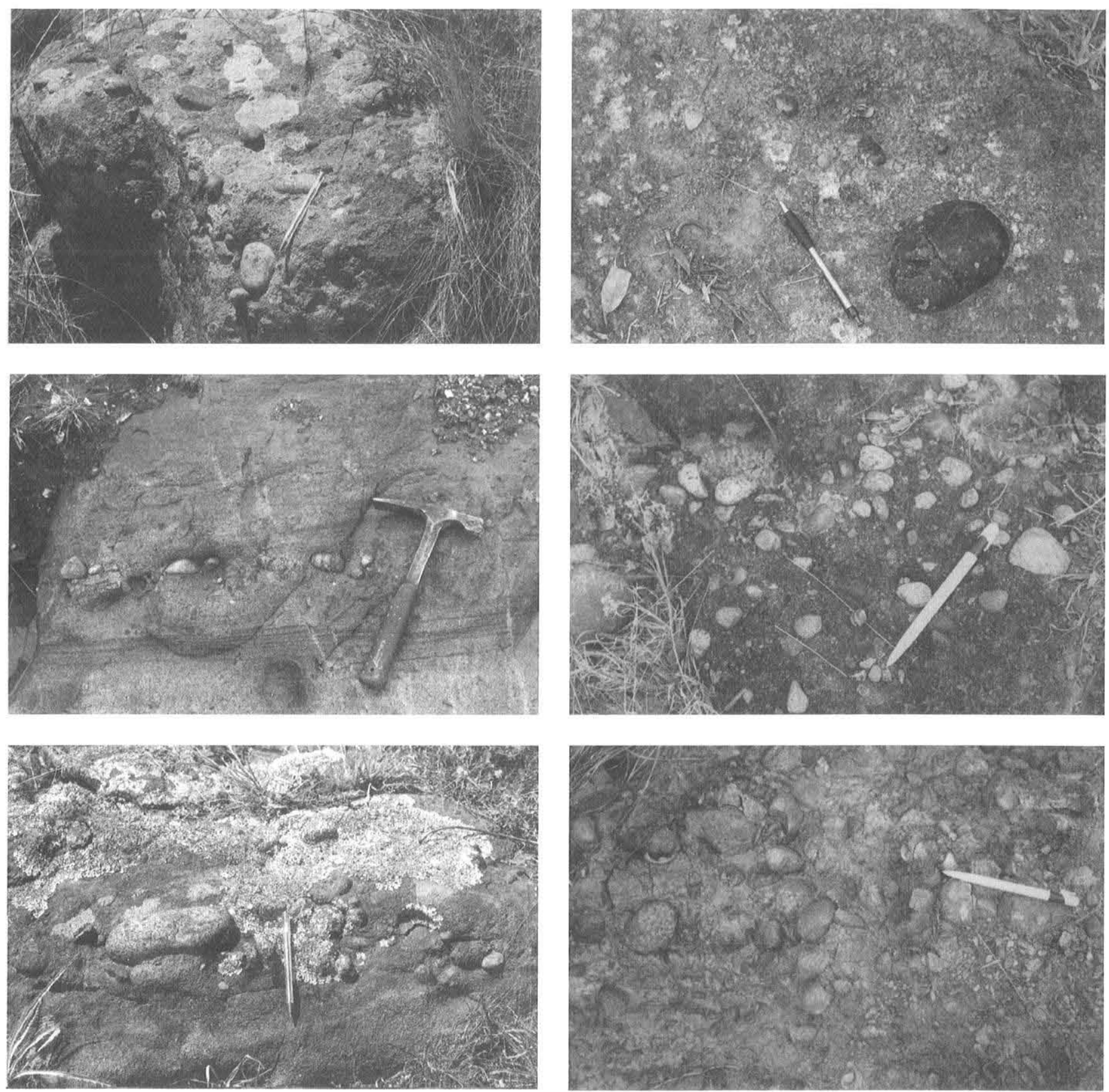

Figura 7- Fotos de seixos e calhaus arredondados a subarredondados do Grupo Maricá

da Bacia do Camaquã. A ausência e/ou raridade de seixos grandes e calhaus vem dificultando seu estudo geocronológico.

A elevada maturidade textural dos fragmentos demonstra um alto grau de retrabalhamento da carga sedimentar. $\mathrm{O}$ arredondamento, a esfericidade e a seleção granulométrica permitem inferir que as áreas fontes encontravam-se distantes dos sítios deposicionais.

De acordo com os dados de paleocorrentes, estas áreas fontes situavam-se predominantemente a sul, conclusão concordante com o acunhamento das formações Passo da Promessa e Arroio América para norte. Estes dados também sugerem que o corpo marinho representado pelos depósitos da Formação São Rafael abria-se para norte, coerente com o espessamento e variação lateral de fácies desta unidade, destacando-se o predomínio de turbiditos neste sentido (Fig. 3).

A ausência de fragmentos correlacionáveis ao Terreno Rio
Vacacaí restringe sua participação à categoria de embasamento. Esta evidência reafirma a independência tectônica do Grupo Maricá, e conseqüentemente de sua bacia, com as atividades tectônicas orogênicas que configuraram as unidades de embasamento do RS (Fragoso-Cesar et al. 2003, Pelosi \& Fragoso-Cesar 2003), pois seus depósitos basais recobrem em discordância o Terreno Rio Vacacaí, que corresponde a mais importante estrutura da Orogenia Brasiliana na região.

Na caracterização das áreas fontes, dois pontos fundamentais foram levantados: (i) situam-se a sul e (ii) contém rochas graníticas diversas de idades do Arqueano e, principalmente, do Paleoproterozóico. Os dados U/Pb em zircão e monazita permitem inferir, até o momento, que as áreas fontes de composição tonalíticas e graníticas do Grupo Maricá apresentavam as seguintes idades aproximadas de cristalização: $\sim 2.6 \mathrm{Ga}, \sim 2.3 \mathrm{Ga}$ e $\sim 2.1 \mathrm{Ga}$. Os dados obtidos também indicam herança isotópica 
Tabela 1 - Dados isotópicos U/Pb em zircão das amostras de álcali feldspato granito (LV45A) e de tonalito (LV 45B).

\begin{tabular}{|c|c|c|c|c|c|c|c|c|c|c|c|c|c|c|c|}
\hline Sample & & & & $\mathrm{Pb} 206$ & $\mathrm{~Pb} 207 *$ & & $\mathrm{~Pb} 206^{*}$ & & Correl. & Pb207* & & $\mathrm{Pb} 206^{*}$ & $\mathrm{~Pb} 207^{*}$ & $\mathrm{~Pb} 207^{*}$ & \\
\hline \multirow[t]{2}{*}{ Fraction } & Size & U & $\mathrm{Pb}$ & Pb204 & U235 & & U238 & & Coeff. & $\mathrm{Pb} 206 *$ & & U238 & U235 & Pb206* & \\
\hline & (mg) & ppm & ppm & (obs.) & & $(\mathrm{pct})$ & & $(p c t)$ & (rho) & & (pct) & Age & Age & Age & (Ma) \\
\hline $\begin{array}{c}\text { LV } 45 \mathrm{~A} \\
\text { E12 }\end{array}$ & 0,019 & 1342 & 553 & 16323 & 8,95779 & 1,16 & 0,397022 & 1,16 & 0,99949 & 0,163638 & 0,0368 & 2155,3 & 2333,7 & 2493,6 & 0,62 \\
\hline $\begin{array}{c}\text { LV 45A } \\
\text { E14 }\end{array}$ & 0,026 & 1227 & 521 & 17970 & 9,34176 & 0,758 & 0,41111 & 0,758 & 0,99942 & 0,164805 & 0,0257 & 2220 & 2372,1 & 2505,6 & 0,43 \\
\hline $\begin{array}{c}\text { LV 45A } \\
\text { E13 }\end{array}$ & 0,02 & 891 & 398 & 19597 & 10,2385 & 0,265 & 0,421054 & 0,264 & 0,995614 & 0,176359 & 0,0248 & 2265,3 & 2456,6 & 2618,9 & 0,41 \\
\hline $\begin{array}{c}\text { LV } 45 A \\
\text { El5 }\end{array}$ & 0,029 & 1141 & 451 & 1868 & 7,83028 & 0,876 & 0,376607 & 0,876 & 0,99918 & 0,150795 & 0,0354 & 2060,4 & 2211,7 & 2355 & 0,6 \\
\hline LV 45A P & 0,01 & 657 & 229 & 9989 & 9,78096 & 0,4 & 0,431418 & 0,4 & 0,9983 & 0,16443 & 0,0233 & 2312,1 & 2414,4 & 2501,7 & 0,4 \\
\hline $\begin{array}{c}\text { LV } 45 \mathrm{~A} \\
\mathrm{R}\end{array}$ & 0,011 & 727 & 422 & 20552 & 13,9957 & 0,414 & 0,506291 & 0,414 & 0,9993522 & 0,200491 & 0,0149 & 2640,8 & 2749,4 & 2830,2 & 0,24 \\
\hline $\begin{array}{c}\text { LV 45A } \\
\text { S }\end{array}$ & 0,014 & 1261 & 492 & 25357 & 8,10641 & 0,136 & 0,388643 & 0,136 & 0,9946582 & 0,151278 & 0,0141 & 2116,5 & 2243 & 2360,4 & 0,24 \\
\hline $\begin{array}{c}\text { LV 45A } \\
\mathrm{U}\end{array}$ & 0,006 & 1222 & 481 & 11156 & 7,84115 & 0,205 & 0,381773 & 0,111 & 0,54127 & 0,148961 & 0,172 & 2084,6 & 2212,9 & 2334 & 2,9 \\
\hline
\end{tabular}

\begin{tabular}{|c|c|c|c|c|c|c|c|c|c|c|c|c|c|c|c|}
\hline \multirow[b]{2}{*}{ Sample } & & & & \multicolumn{4}{|c|}{$\begin{array}{l}\text { Radiogenic Rations } \\
\text { (isoplot Data) }\end{array}$} & & \multirow[b]{2}{*}{ Correl. } & \multirow[b]{2}{*}{$\mathrm{Pb} 207^{*}$} & & \multirow[b]{2}{*}{$\mathrm{Pb} 206^{*}$} & \multirow[b]{2}{*}{$\mathrm{Pb} 207^{*}$} & \multirow[b]{2}{*}{$\mathrm{Pb} 207^{*}$} & \\
\hline & & & & $\mathrm{Pb} 206$ & $\mathrm{~Pb} 207^{*}$ & & Pb206* & & & & & & & & \\
\hline Fraction & Size & $\mathrm{U}$ & $\mathrm{Pb}$ & $\mathrm{Pb} 204$ & U235 & & U238 & & Coeff. & Pb206* & & U238 & U235 & Pb206* & \\
\hline & $(\mathrm{mg})$ & ppm & $\mathrm{ppm}$ & (obs.) & & (pct) & & (pct) & (rho) & & (pet) & Age & Age & Age & (Ma) \\
\hline LV 45B K & 0,021 & 432 & 210 & 1899 & 10,2391 & 0,429 & 0,44519 & 0,429 & 0,998 & 0,166721 & 0,0217 & 2374,9 & 2456,6 & 2525 & 0,36 \\
\hline LV 45B L & 0,027 & 606 & 307 & 24183 & 12,4027 & 0,715 & 0,468055 & 0,715 & 0,999 & 0,192184 & 0,0132 & 2475 & 2635,4 & 2760,9 & 0,22 \\
\hline $\begin{array}{c}\text { LV 45B } \\
\mathrm{M}\end{array}$ & 0,027 & 275 & 142 & 12191 & 12,0754 & 0,264 & 0,474277 & 0,264 & 0,998 & 0,184659 & 0,0137 & 2502,3 & 2610,3 & 2695,2 & 0,23 \\
\hline LV 45B N & 0,021 & 478 & 227 & 19566 & 10,1717 & 0,525 & 0,445397 & 0,525 & 0,999 & 0,165632 & 0,0122 & 2374,8 & 2450,5 & 2514 & 0,21 \\
\hline LV 45B O & 0,022 & 379 & 183 & 11198 & 10,5036 & 0,386 & 0,450888 & 0,383 & 0,9980 & 0,168954 & 0,0197 & 2399,2 & 2480,2 & 2547,3 & 0,33 \\
\hline LV 45B P & 0,018 & 469 & 245 & 6551 & 11,7213 & 2,45 & 0,490826 & 2,45 & 0,999 & 0,1732 & 0,1 & 2574,2 & 2582,4 & 2588,8 & 1,7 \\
\hline LV 45B S & 0,012 & 742 & 388 & 6747 & 14,1451 & 0,32 & 0,490334 & 0,316 & 0,986 & 0,209224 & 0,052 & 572,1 & 2759,5 & 2899,6 & 0,84 \\
\hline
\end{tabular}
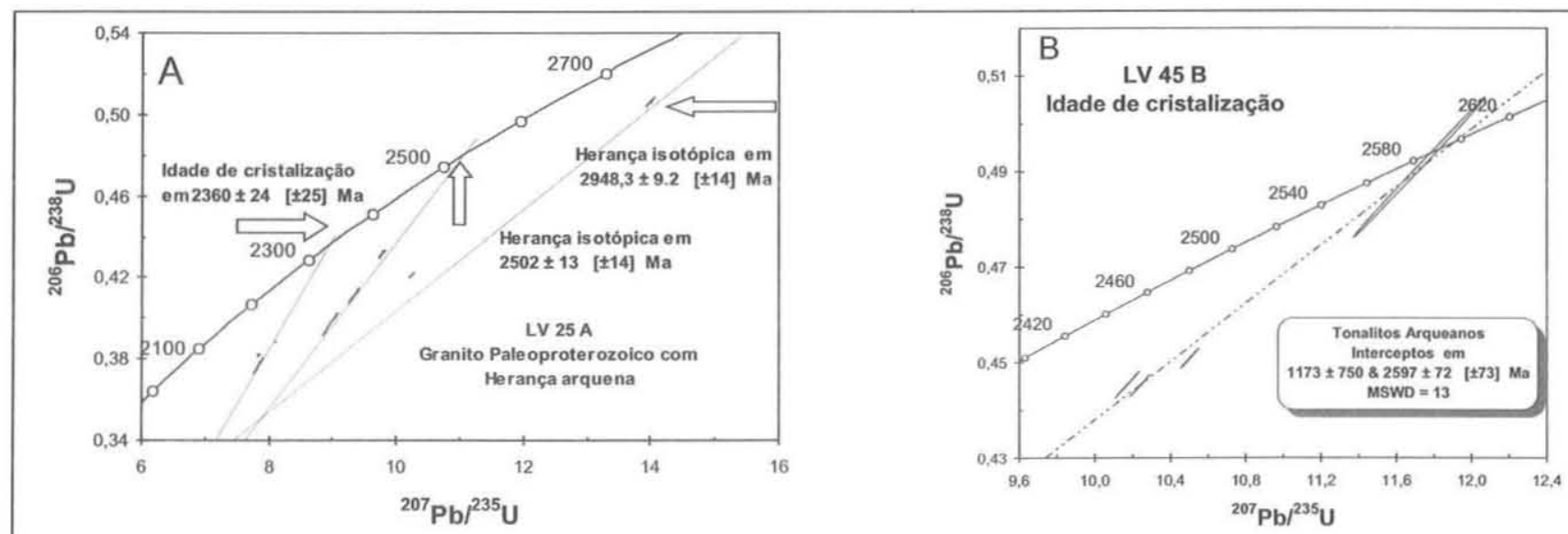

Figura 8-Diagramas ${ }^{207} \mathrm{~Pb} /{ }^{235} \mathrm{U} x{ }^{206} \mathrm{~Pb} /{ }^{238} \mathrm{U}$ em zircão. A - Diagrama da amostra de calhau de álcali feldspato granito foliado (LV $45 \mathrm{~A})$; B-Diagrama da amostra de calhau de tonalito maciço( $L V 45 B)$.

arqueana ao redor de 2.5 e $2.9 \mathrm{Ga}$.

Na porção brasileira do Cráton Rio de La Plata (Bloco Valentines; Fig. 1B) são descritas rochas metamórficas de alto grau (Complexo Santa Maria Chico de Nardi \& Hartmann 1979) com idades U/Pb SHRIMP de geração e metamorfismo entre 2.5-2.0 Ga (Chemale Jr. 2000, Hartmann et al. no prelo apud Soliani Jr. et al. 2000). Na porção uruguaia, os dados U/Pb SHRIMP apontam intervalos similares, com idades entre 2.17-1.97 Ga (Hartmann et al. 2001, Bossi \& Campal 2003, Maldonado et al. 2003) para as rochas plutônicas do Bloco Florida (Fig. 1B) ou, como também é conhecido, Terreno Piedra Alta (Bossi et al. 1993, Maldonado et al. 2003, Bossi \& Campal 2003). As rochas do Bloco Florida são intrudidas por uma série de diques máficos do Estateriano (1.7-1.8 Ga; Bossi et al. 1993). Considerando 
Tabela 2 - Dados isotópicos U/Pb em monazita da amostra de granito milonitizado com granada (SF 1A).

\begin{tabular}{|c|c|c|c|c|c|c|c|c|c|c|c|c|c|c|c|c|c|}
\hline SPU & Magn. & $\begin{array}{l}207 / \\
235 \#\end{array}$ & Error & $\begin{array}{l}206 / \\
238 \#\end{array}$ & Error & COEF. & $\begin{array}{l}238 / \\
206\end{array}$ & Error & $\begin{array}{l}207 / \\
206 \#\end{array}$ & Error & $\begin{array}{l}206 / \\
204^{*}\end{array}$ & $\mathrm{~Pb}$ & U & Weight & $\begin{array}{l}206 / \\
238\end{array}$ & $\begin{array}{l}2071 \\
235\end{array}$ & $\begin{array}{l}2071 \\
206\end{array}$ \\
\hline & Frac. & & $(\%)$ & & (\%) & & & $(\%)$ & & $(\%)$ & & (ppm) & (ppm) & (mg) & $\begin{array}{c}\text { Age } \\
\text { (Ma) }\end{array}$ & $\begin{array}{l}\text { Age } \\
\text { (Ma) }\end{array}$ & $\begin{array}{c}\text { Age } \\
\text { (Ma) }\end{array}$ \\
\hline \multicolumn{18}{|l|}{ SF1A } \\
\hline 2487 & 1 & $\begin{array}{c}7,194 \\
99\end{array}$ & 1,38 & $\begin{array}{c}0,396 \\
323\end{array}$ & 1,28 & $\begin{array}{c}0,9952 \\
669\end{array}$ & $\begin{array}{c}2,523194 \\
465\end{array}$ & 1,28 & $\begin{array}{c}0,131 \\
668\end{array}$ & 0,134 & 388,6 & 16373,0 & 2285,0 & 0,003 & 2152 & 2136 & 2120 \\
\hline 2488 & 2 & $\begin{array}{c}7,058 \\
25\end{array}$ & 0,47 & $\begin{array}{c}0,390 \\
542\end{array}$ & 0,467 & $\begin{array}{c}0,9937 \\
368\end{array}$ & $\begin{array}{c}2,560544 \\
064\end{array}$ & 0,467 & $\begin{array}{c}0,131 \\
077\end{array}$ & 0,0525 & 4499,0 & 10632,0 & 1550,9 & 0,007 & 2125 & 2119 & 2112 \\
\hline 2489 & 3 & $\begin{array}{c}6,996 \\
45\end{array}$ & 0,474 & $\begin{array}{c}0,387 \\
505\end{array}$ & 0,471 & $\begin{array}{c}0,9936 \\
936\end{array}$ & $\begin{array}{c}2,580611 \\
863\end{array}$ & 0,471 & $\begin{array}{c}0,130 \\
948\end{array}$ & 0,0531 & 7489,4 & 9293,9 & 1484,8 & 0,007 & 2111 & 2111 & 2111 \\
\hline
\end{tabular}

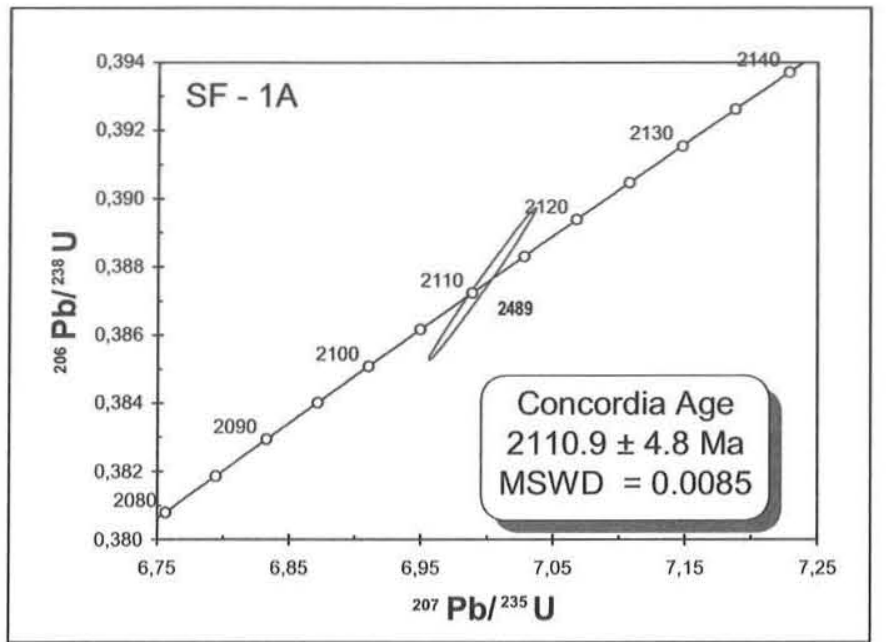

Figura 9 - Diagrama de concórdia da amostra de granito milonitizado com granada (SF 1A), analisada pelo método U/Pb em monazita.

estes intervalos de idades e o posicionamento a sul destas áreas cratônicas de embasamento, podemos interpretar que as rochas do Cráton Rio de La Plata provavelmente serviram como áreas fontes para os depósitos do Grupo Maricá.

Outra possível área fonte situa-se na porção uruguaia do Cinturão Dom Feliciano (Hartmann et al. 2001, Bossi \& Campal 2003), cujos dados U/Pb SHRIMP em amostras de tonalitos indicam idades de geração entre 3.4-2.7 Ga, além de rochas graníticas leucocráticas com idade de 2.7 Ga no núcleo do zircão e de 2.1 Ga nas bordas (Hartmann et al. 2001). Na porção brasileira deste cinturão, dados U/Pb SHRIMP obtidos por Porcher et al. (no prelo apud Soliani Jr. et al. 2000) em gnaisses tonalíticos da Serra das Encantadas apontam idades de geração e metamorfismo entre 2.2-2.0 Ga. Porém, acreditamos que dificilmente estas áreas de embasamento paleoproterozóico da Serra das Encantadas tenham papel como área fonte, já que se situam a leste das áreas de exposição do Grupo Maricá e, além de pequenas exposições gnáissicas e graníticas de seu embasamento (Complexo Encantadas), dominam cristas de quartzo-milonitos, milonitos e filonitos com escassa a ausente contribuição como área fonte.

Desta forma, interpretamos no presente trabalho, o Cráton Rio de La Plata e algumas unidades de embasamento arqueano e paleoproterozóico do Cinturão do Feliciano no Uruguai como prováveis áreas fontes para o Grupo Maricá.

A caracterização do Cráton Rio de La Plata como a entidade que contém as principais áreas fontes para o Grupo Marica invalida hipótese de um modelo de antefossa (bacia de foreland ou de antepaís) do Cinturão Dom Feliciano (Fragoso-Cesar et al. 1985, Paim et al. 1995, 2000) para a Bacia do Camaquã. Por outro lado, reforça o modelo de um ambiente anorogênico intraplaca para esta bacia, desvinculado tanto da evolução do Cinturão Dom Feliciano quanto do Ciclo Brasiliano

Os estudos litofaciológicos realizados nas sucessões fluviais (formações Passo da Promessa e Arroio América) e marinhas (Formação São Rafael) do Grupo Maricá (Pelosi 2005) sugerem que estas se desenvolveram em uma bacia ampla, sem grandes variações laterais de fácies. Estes elementos, associados à caracterização de uma área fonte cratônica, permitem inferir que o Grupo Maricá se depositou em uma bacia intracratônica, sem qualquer evidência de contribuição relacionada à atividade orogênica contemporânea.

Agradecimentos Os autores gostariam de agradecer à Fundação de Amparo à Pesquisa do Estado de São Paulo (FAPESP) pelo apoio financeiro (processo 00/07510-4) e pela bolsa de doutorado concedida à Ana Paula M. R. Pelosi (processo 01/01112-0). À Elton Dantas do Laboratório de Geocronologia da Universidade de Brasília, pela coordenação das análises geocronológicas e sugestões ao manuscrito. Agradecemos também aos colegas Gelson Luis Fambrini, Renato Paes de Almeida, Liliane Janikian, Chahrazéd Layaun Morenghi e Ana Paula Justo. Aos professores do IGc/USP Claudio Riccomini, José Moacyr Vianna Coutinho e Johann Hans Daniel Schorscher. À Miguel Ângelo Stipp Basei do Centro de Pesquisas Geocronológicas da Universidade de São Paulo.

\section{Referências}

Almeida R P. 2001. Evolução tectono-sedimentar da Formação Santa Bárbara na Sub-Bacia do Camaquã Ocidental, RS. Dissertação de Mestrado, Instituto de Geociências, Universidade de São Paulo, 160p.

Almeida R.P. 2005. Tectônica e Sedimentação do Ediacarano ao Ordoviciano: os exemplos do Supergrupo Camaquã (RS) e Grupo Caacupe (Paraguai Oriental). Tese de Doutoramento Instituto de Geociências, Universidade de São Paulo, 203p.
Babinski M., Chemale Jr. F., Hartmann L. A., Van Schmus W.R., Silva L.C. da. 1996. Juvenile accretion at 750-700 Ma in southern Brazil. Geology, 24 (5): 439-442.

Bongiolo E.M., Mexias A.S., Santos J.O.S., Hartmann L. A., Conceição R.V., Gomes M.E.B., Formoso M.L.L. 2003. Geocoronologia do hidrotermalismo versus magmatismo no distrito aurifero de Lavras do Sul/RS. In: SBG-RS Encontro sobre a estratigrafia do RS: Escudo e Bacias, 1, Bol. Res., p.83-88. 
Bossi J. \& Campal N. 2003. Estratigrafia Del basamento predevonico de Uruguay: Terrenos-estratigráficos y geocronologia. In: SBG-RS Encontro sobre a estratigrafia do RS: Escudo e Bacias. SBG. Bol. Res, p. 43-48.

Bossi J., Campal N., Civetta L., Girardi V.A.V., Mazzuchelli M., Negrini L., Rivalenti G., Fragoso-Cesar A.R.S., Sinigoi S., Teixeira W., Piccirillo E.M., Molesini M. 1993. Early Proterozoic dike swarms from western Uruguay: geochemistry, $\mathrm{Sr}-\mathrm{Nd}$ isotopes and petrogenesis. Chemi. Geol., 106(3-4): 263-277.

Carvalho P.F. 1932. Reconhecimento Geológico no Estado do Rio Grande do Sul. Bol. Serv. Geol. Mineral., 66:1-72.

Chemale Jr. F. 2000. Evolução geológica do Escudo Sul-rio-grandense. In: M. Holz \& L.F. De Ros (eds) Geologia do Rio Grande do Sul. CIGO/UFRGS, pp:13-52.

Chemale Jr. F., Hartmann L.A., Babinski M., Wildner W., Van Schmus W.R. 1994. Evolução tectônica do Bloco São Gabriel, RS. In: SBG, Congr. Bras. Geol, 38, Boletim Resumos Expandidos, v. 1, p. 232233.

Fambrini G.L. 2003.O Grupo Santa Bárbara (Neoproterozóico III) da Bacia do Camaquã, Rio Grande do Sul. Tese de Doutoramento, Instituto de Geociências, Universidade de São Paulo, 264p.

Fragoso-Cesar A.R.S. 1991. Tectônica de Placas no Ciclo Brasiliano: as orogenias dos Cinturões Dom Feliciano e Ribeira no Rio Grande do Sul. Tese de Doutoramento, Instituto de Geociências, Universidade de São Paulo, 366 p.

Fragoso-Cesar A.R.S., Almeida R.P., Fambrini G.L., Pelosi A.P.M.R., Janikian L. 2003. A Bacia Camaquã: um sistema de intracontinental anorogênico de rifts do Neoproterozóico III-Eopaleozóico no Rio Grande do Sul. In: SBG-RS, Encontro sobre a Estratigrafia do RS: Escudo e Bacias, 1, Bol. Res., pp:139-144.

Fragoso-Cesar A.R.S, Faccini U.F., Paim P.S.G., Lavina E.L., Altamirano J.A.F. 1985. Revisão na Estratigrafia das Molassas do Ciclo Brasiliano no Rio Grande do Sul. In: Simp. Sul-Brasileiro de Geol., 2., Anais, 477-491.

Fragoso-Cesar A.R.S., Fambrini G.L., Riccomini C., Janikian L., Almeida R.P., Pelosi A.P.M.R., Machado R. 2001. Estruturas induzidas por abalos sísmicos na Formação Santa Bárbara (neoproterozóico III-eocambriano), Bacia do Camaquã, RS: o exemplo do Passo da Capela. Rev. Bras. Geoc. 31(2): 155-162.

Hartmann L.A. Campal N., Santos J.O.S., McNaugton N.J. Schipilov A., Lafon J. 2001. Archean crust in the Rio de La Plata Craton, Uruguay: SHIRIMP U-Pb zircon reconnaissance geochronology. Juor. South Am. Earth. Sci. 14: 557-570.

Ibbeken H. \& Schleyer R. -1991- Source and Sediment - A case study of provenance and mass balance at an active plate margin (Calabria, southern Italy). Springer-Verlag, Berlin Heidelberg, 286 p.

Janikian L., Almeida R.P. Fragoso-Cesar A.R.S., Fambrini G.L. 2003. Redefinição do Grupo Bom Jardim (Neoproterozóico III) em sua área-tipo: litoestratigrafia, paleogeografia e significado tectônico das sucessões vulcano-sedimentares do Supergrupo Camaquã, RS. Rev. Bras. Geol. 33(4): 347-360

Krogh T.E. 1973. A low-contamination method for hydrothermal decomposition of zircon and extraction of $\mathrm{U}$ and $\mathrm{Pb}$ for isotopic age determinations. Geochi. at Cosmoch. Acta, 37:485-494.

Laux J.H., Pimentel M.M., Dantas E.L., Armstrong R., Armele A., Nilson A.A. 2004. Mafic magmatism associated with Goiás magmatic arc in Anincus region, Goiás, central Brazil:Sm-Nd isotopes and new ID-TIMS SHIMP U-Pb data. Juor. South Am. Earth. Sci. 16(7):599614.

Lavina E.L., Faccini U.F., Paim P.S.G., Fragoso-Cesar A.R.S. 1985 Ambientes de sedimentação da Bacia do Camaquã, Eo-Paleozóico do Rio Grande do Sul. Acta Geol. Leopol., 21( 9): 185-227.

Leinz V., Barbosa A.F., Teixeira G.A. 1941. Mapa Geológico CacapavaLavras. Bol. Div. Prod. Min. Secr. Agri. Ind. e Com. Porto Alegre, v. 90, pp.:1-39.

Leite J.A.D. 1995. Datação Schrimp U/Pb em zircões e o exemplo de dois corpos graníticos contrastantes no Escudo Sul-Riograndense. In: Simp. Sul-Brasileiro de Geologia,6/ Encontro de Geologia do Cone Sul,1, Res. Expan., 5-12.

Leites S.R., Lopes R.C., Wildner W., Porcher C.A., Sander A. 1990. Divisão litofaciológica da Bacia do Camaquã na Folha Passo do Salsinho, Caçapava do Sul -RS, e sua interpretação paleoambiental. In: SBG,
Congr. Bras. Geol., 36, Anais, v.1, p. 300-312.

Ludwing K.R. 1993. PBDAT. A computer program for processing UPbTh isotope data. USGS Open File Reporter, 88-542, 34p.

Ludwing K.R. 2001. Users' manual for Isoplot/Ex version 2.47. A geochronological toolkit for Microsoft Excel. Berkeley Geochronological Center Special Publication, 55p.

Machado N., Kope J.C., Hartmann L.A. 1990. A Late Proterozoic U-Pb age for the Bossoroca Belt, Rio Grande do Sul, Brazil. Jou. South Am. Earth Sci. 3(2/3): 87-90.

Maldonado S., Piñeyro D., Schipilov A., Bossi J. 2003 El Transamazoniano en Uruguay - Terreno Piedra Alta. In: SBG-RS, Encontro sobre a Estratigrafia do RS: Escudo e Bacias, 1, Bol. Res., p:71-76.

Miall A.D. 1974. Palaeocurrent analysis of alluvial sediments: a discussion of directional variance and vector magnitude. J Sediment. Petrol., 44 (4):1174-1185.

Miall A.D. 1990. Principles of sedimentary basin analysis. $2^{\text {nd }}$ ed., New York, Springer-Verlag, $668 \mathrm{pp}$.

Morenghi C.L., Pelosi A.P.M. R., Fragoso-Cesar A.R.S. 2002. Caracterização litofaciológica dos depósitos fluviais da Formação Maricá (Neoproterozóico III) Rio Grande do Sul. In: SBG, Cong. Bras. Geol., 41, Anais, p320.

Nardi L.S.V. \& Hartmann L.A. 1979. O Complexo Santa Maria Chico do Escudo Sul-rio-grandense. Acta Geol. Leopol., 6: 45-75p.

Paim P.S.G. 1994. Depositional Systems and Paleogeographical Evolution of the Camaquã and Santa Bárbara Basins, Brazil. Philosofer Doctor Thesis, University of Oxford. v.I, 277 p.

Paim P.S.G., Chemale Jr. F., Lopes R.C. 2000. A Bacia do Camaquã. In: M. Holtz \& L.F. De Ros (eds.) Geologia do Rio Grande do Sul, pp:231-274.

Paim P.S.G., Lopes R.C., Chemale Jr. F. 1995. Aloestratigrafia, sistemas deposicionais e evolução paleogeográfica da Bacia do Camaquã Vendiano Superior/ Ordoviciano Inferior do RS. In: Simp. Sul-Brasileiro de Geologia,6/ Encontro de Geologia do Cone Sul,1., Res. Expan., 39-50.

Pelosi A.P.M.R. 2001. Evolução paleogeográfica das formações Maricá e Crespos (Neoproterozóico III) na porção norte de Sub-Bacia do Camaquã Ocidental, Caçapava do Sul, RS. SP. Dissertação de Mestrado, Instituto de Geociências, Universidade de São Paulo, S. Paulo, $153 \mathrm{p}$.

Pelosi A.P.M.R. 2005. Evolução paleogeográfica do Grupo Maricá, Neoproterozóico pré-600 Ma do Rio Grande do Sul. Tese de Doutoramento, Instituto de Geociências, Universidade de São Paulo, 147p.

Pelosi A.P.M.R. \& Fragoso-Cesar. 2003. Proposta litoestratigráfica e considerações paleoambientais sobre o Grupo Maricá (Neoproterozóico III), Bacia do Camaquã, Rio Grande do Sul. Rev. Bras. Geoc. 33 (2):137-148.

Pelosi A.P.M.R., Morenghi C.L., Fragoso-Cesar A.R.S. 2002. Análise de Proveniência da Formação Maricá, Neoproterozóico III do RS. In: SBG, Cong. Bras. Geol. 41, Anais, p670.

Pettijohn F.J., Potter P.E., Siever R. 1973. Sand and sandstone. SpringerVelarg $617 \mathrm{p}$.

Porcher C.A., Leites S.R., Ramgrab G.E., Camozzato E. 1995. Mapa geológico da Folha Passo do Salsinho, estado do Rio Grande do Sul. Programa de levantamentos geológicos básicos do Brasil. CPRMRS, 339p.

Potter P.E. \& Pettijohn F.J. 1977. Paleocurrents and basin analysis. $2^{\text {nd }}$ ed., Springer-Verlag, New York, $425 \mathrm{p}$.

Powers M.C. 1953. A new roundness scale for sedimentary particles. Jour: Sediment. Petrol., 23: 117-119.

Remus M.V.D., McNaughton N.J., Hartmann L.A., Fletcher I.R. 1997. U-Pb SHIRIMP zircon dating and Nd isotope data of granitoids of São Gabriel Block, Southern Brazil: evidence for Archean/Paleoproterozoic basement. In: Internat. Simp. on granites and associated mineralizations, 2, Exten. Abstracts., v. 1, p. 217-272.

Ribeiro M. 1983. Informes sobre a Formação Maricá. Inheríngia, Série Geologia, 7: 1-50

Ribeiro M., Bocchi P.R., Figueiredo Filho P.M., Tessari R.I. 1966. Geologia da Quadrícula de Caçapava do Sul, Rio Grande do Sul. Bol. Div. Fom. Prod. Min. 127: 1-232.

Ribeiro M. \& Fantinel L.M. 1978 Associações petrotectônicas do Escudo Sul-Riograndense: I Tabulação e distribuição das associações petrotectônicas do Escudo do Rio Grande do Sul. Inheringia, Série 
Geologia, 5: 19-54.

Robertson J.F. 1966. Revision of stratigraphy and nomenclature of rock units in Caçapava Lavras Region. Notas e Estudos, IG-UFRGS, 1( 2): $41-54$.

Soliani Jr. E. 1986. Os dados geocronológicos do Escudo Sul-Riograndense e suas implicações de ordem geotectônica. Tese de Doutoramento, Instituto de Geociências, Universidade de São Paulo, 425 p.

Soliani Jr. E., Koester E., Fernández L.A.D. 2000. A geologia isotópica do Escudo Sul-rio-grandense - Parte II: os dados isotópicos e interpretações petrogenéticas. In: M. Holtz \& L.F. De Ros (eds.) Geologia do Rio Grande do Sul, pp:175-230.
Tessari R.I.\& Giffoni L.E. 1970. Geologia da região de Piratini, Pinheiro Machado e Bagé, Rio Grande do Sul. Bol. Div. Geol. Miner, 246: $1-122$.

Tucker M. 1993. The field description of sedimentary rocks. $2^{\circ} \mathrm{ed}$. Geol. Soc. London, Handbook Series, 153p.

Manuscrito A1551

Aprovado em 30 de outubro de 2006 